\title{
Selection of covalent organic framework pore functionalities for differential adsorption of
} microcystin toxin analogues

Soraia P. S. Fernandes, ${ }^{\mathrm{a}, \mathrm{b}}$ Petr Kovář, ${ }^{\mathrm{c}}$ Milan Pšenička, ${ }^{\mathrm{c}}$ Artur M. S. Silva, ${ }^{\mathrm{b}}$ Laura M. Salonen, ${ }^{* a}$ and Begoña Espiña*a

a International I berian Nanotechnology La boratory(INL), Aveni da Mes tre José Veiga, 4715-330 Braga, Portugal e-mail:Iaura.salonen@inl.int; begona.espina@inl.int

${ }^{b}$ As sociate Laboratory for Green Chemistry-Network of Chemi stry a nd Technology (LAQV-REQUIMTE), Department of Chemistry, University of Aveiro, Campus Universitá rio de Sa ntiago, 3810-193 Avei ro, Portugal

${ }^{c}$ Charles University, Fa culty of Mathematics and Physics, Ke Karlovu 3, 121 16 Prague, Czech Republic 


\section{Materials and Methods}

\section{Reagents and Chemicals}

Triformylphloroglucinol (Tp) was synthesized following a literature-known procedure. ${ }^{1}$ 3,3'-Bis(trifluoromethyl)benzidine from Apollo Scientific, anhydrous 1,4-dioxane from Acros Organics, and mesitylene 99\% extra pure from Fisher Chemical were used for the synthesis of TpBD- $\left(\mathrm{CF}_{3}\right)_{2}$. For the synthesis of TpBD- $\left(\mathrm{NO}_{2}\right)_{2}, 3,3^{\prime}$-dinitrobenzidine and anisole were purchased from $\mathrm{TCl}$ Chemicals. Tin(II) chloride dihydrate (>98\%) and anhydrous THF were purchased from Acros Organics for the synthesis of TpBD- $\left(\mathrm{NH}_{2}\right)_{2}$. Aqueous acetic acid and hydrochloric acid were prepared by dilution of commercial acetic acid, ACS reagent, $\geq 99.8 \%$ from Sigma-Aldrich, and the commercial hydrochloric acid, 37\% from Fisher Chemical. $\mathrm{N}, \mathrm{N}$-Dimethylformamide HPLC grade and tetrahydrofuran HPLC grade from Fisher Chemical, and acetone $99.5 \%$ from Honeywell were used as received for the washing of the resulting products.

Ultrapure water was produced by Milli-Q Advantage A10 system (Millipore, resistivity: $18.2 \mathrm{M} \Omega \mathrm{cm}^{-1}$ ).

Microcystin-LR, -LA, -RR, and -YR isolated from Microcystis aeruginosa sp. were purchased from Enzo Life Sciences. 6,8-Difluoro-4-methylumbelliferylphosphate (DIFMUP) was purchased from Thermo Fisher Scientific. Protein phosphatase-1 catalytic subunit (PP1), $\alpha$-isoform from rabbit, $5000-15000$ units $\mathrm{mg}^{-1}$ of protein was purchased from Sigma-Aldrich.

\section{Characterization}

Small-angle X-ray scattering (SAXS) measurements were performed in an Anton Paar SAXSess $\mathrm{mc2}$ instrument operating at $40 \mathrm{kV}$ and $50 \mathrm{~mA}$. Data were collected with an image plate detector. Samples were placed into a holder with Mylar windows for the measurement. Data are background corrected.

X-ray diffraction (XRD) analyses were performed on a PANalytical X'Pert PRO MRD diffractometer operating at $45 \mathrm{Kv}$ and $40 \mathrm{~mA}$.

Thermogravimetric analyses (TGA) were carried out on a TGA/DSC 1 STAR ${ }^{\text {s }}$ system (MettlerToledo). The samples were heated from 298.15 to $1173.15 \mathrm{~K}$ at $283.15 \mathrm{~K} \mathrm{~min}^{-1}$ under a continuous Ar flow of $50 \mathrm{~mL} \mathrm{~min}$.

Infrared (IR) spectra were recorded on a Bruker VERTEX 80v FT-IR spectrometer in ATR mode. IR data is background corrected and reported in frequency of adsorption $\left(\mathrm{cm}^{-1}\right)$.

Nitrogen sorption measurements were performed using a Quantachrome Autosorb IQ2 automated analyser. Prior to the measurements, samples were outgassed by heating to $120{ }^{\circ} \mathrm{C}$ (heating rate: $5{ }^{\circ} \mathrm{C} \quad \mathrm{min}^{-1}$, dwelling time: $720 \mathrm{~min}$ ). Multipoint Brunauer-Emmett-Teller (BET) method using ASIQwin ${ }^{\mathrm{TM}}$ software was used to estimate the surface areas of the obtained powders. Pore size distributions were assessed using quenched-solid density functional theory (QSDFT) equilibrium model for slit pores $\left(\mathrm{N}_{2}\right.$ at $77 \mathrm{~K}$ on carbon). 
The contact angle measurements were performed under air at $19{ }^{\circ} \mathrm{C}$ with a Drop Shape Analyzer DSA100 from Krüss. COF powders were homogenized with pestle and mortar to avoid large aggregates and to diminish the effect of the roughness in the measurements. The COF powder was placed on a transparent tape and pressed against another piece of tape. After peeling the second layer, a uniform layer of each COF was obtained for the contact angle measurements.

Scanning electron microscopy (SEM) studies were performed using a Quanta 650 fieldemission scanning electron microscope operating at $3 \mathrm{kV}$ and employing an Everhardt Thornley secondary electrons detector, with a working distance of around $10 \mathrm{~mm}$. The samples were prepared by adhesion of the sample powder directly on a conductive double-sided copper tape attached to SEM pin stub. 


\section{COF Synthesis}

\section{Synthesis of TpBD- $\left(\mathrm{CF}_{3}\right)_{2}$}

TpBD- $\left(\mathrm{CF}_{3}\right)_{2}$ was synthesized according to our previous report, ${ }^{2}$ in a $100 \mathrm{~mL}$ pressure tube (ACE glass, bushing type back seal, $17.8 \mathrm{~cm} \times 38.1 \mathrm{~mm}$ ). Into the pressure tube, Tp (370 mg, $1.76 \mathrm{mmol}, 1.0$ equiv) and 3,3'-bis(trifluoromethyl)benzidine (845 mg, $2.64 \mathrm{mmol}, 1.5$ equiv) were dispersed in a $(1: 1,12 \mathrm{~mL})$ mixture of 1,4-dioxane and mesitylene. The suspension was stirred and sonicated at r.t. for $2 \mathrm{~min}$ to obtain a homogeneous dispersion. Then, aqueous $6 \mathrm{M}$ acetic acid (1.47 mL, $8.8 \mathrm{mmol}, 5$ equiv) was added, and the mixture was heated to $120^{\circ} \mathrm{C}$. The reaction mixture was stirred at $120{ }^{\circ} \mathrm{C}$ for $3 \mathrm{~d}$ and allowed to reach r.t. Solid was collected by filtration and washed with DMF $(5 \times 25 \mathrm{~mL}), \mathrm{H}_{2} \mathrm{O}(2 \times 25 \mathrm{~mL})$, and acetone $(3 \times 25 \mathrm{~mL})$, for period of $1 \mathrm{~h}$ each. The resulting solid was dried under high vacuum at $120{ }^{\circ} \mathrm{C}$ for $6 \mathrm{~h}$, to give $964 \mathrm{mg}$ of TpBD- $\left(\mathrm{CF}_{3}\right)_{2}$ as yellow-orange solid.

\section{Synthesis of TpBD-( $\left.\mathrm{NO}_{2}\right)_{2}$}

TpBD- $\left(\mathrm{NO}_{2}\right)_{2}$ was synthesized following a literature-known procedure. ${ }^{3}$ In a Duran glass bottle (DURAN $^{\circledast}, 25 \mathrm{~mL}, 3.6 \mathrm{~cm} \times 7.0 \mathrm{~cm}$ ), to a mixture of $\mathrm{Tp}(52 \mathrm{mg}, 0.25 \mathrm{mmol}, 1.0$ equiv) and 3,3'-dinitrobenzidine (101 $\mathrm{mg}, 0.37 \mathrm{mmol}, 1.5$ equiv) was added anisole $(8 \mathrm{~mL}$ ), and an aqueous solution of $12 \mathrm{M}$ acetic acid $(2 \mathrm{~mL})$. The mixture was sonicated for 10 min at r.t. to furnish a homogeneous mixture. Then, the reaction mixture, without stirring, was heated at $120{ }^{\circ} \mathrm{C}$ for $4 \mathrm{~d}$. The red solid was filtered and washed with acetone $(\approx 200 \mathrm{~mL})$. Then, in a Duran glass bottle, the resulting COF powder was re-suspended in anisole $(5 \mathrm{~mL})$, heated at $120{ }^{\circ} \mathrm{C}$ for $1 \mathrm{~d}$ and allowed to reach r.t. Red powder was collected by filtration and washed with acetone $(6 \times 30 \mathrm{~mL})$ until a colorless filtrate was observed. The obtained powder was dried under high vacuum at $120{ }^{\circ} \mathrm{C}$ for $6 \mathrm{~h}$ to afford $125 \mathrm{mg}$ of $\mathrm{TpBD}-\left(\mathrm{NO}_{2}\right)_{2}$ as red solid.

\section{Synthesis of TpBD- $\left(\mathrm{NH}_{2}\right)_{2}$}

TpBD- $\left(\mathrm{NH}_{2}\right)_{2}$ was synthesized following a literature-known procedure. ${ }^{3}$ In a $50 \mathrm{~mL}$ round-bottom flask, $\mathrm{SnCl}_{2} \cdot 2 \mathrm{H}_{2} \mathrm{O}(1500 \mathrm{mg}, 6.65 \mathrm{mmol})$ was dissolved in anhydrous THF $(3 \mathrm{~mL})$. To the solution was added TpBD- $\left(\mathrm{NO}_{2}\right)_{2}(71.2 \mathrm{mg})$, and the resulting suspension was heated under reflux for $3 \mathrm{~h}$. The brown powder was collected by filtration and suspended in aqueous $1 \mathrm{M} \mathrm{HCl}(10 \mathrm{~mL}, 30 \mathrm{~min})$. Then, the precipitate was collected by filtration and washed with $1 \mathrm{M} \mathrm{HCl}(10 \times 10 \mathrm{~mL})$, water $(3 \times 10 \mathrm{~mL})$, and THF $(3 \times 10 \mathrm{~mL})$, with period of $1 \mathrm{~h}$ per wash. The resulting solid was dried under high vacuum at $120{ }^{\circ} \mathrm{C}$ for $6 \mathrm{~h}$ to give $55 \mathrm{mg}$ of TpBD- $\left(\mathrm{NH}_{2}\right)_{2}$ as brown solid. 


\section{Theoretical Calculations}

Molecular simulations were used to describe the structure arrangement and the adsorption mechanism of the toxins on TpBD- $\left(\mathrm{NO}_{2}\right)_{2}, \mathrm{TpBD}-\left(\mathrm{NH}_{2}\right)_{2}$, and TpBD- $\left(\mathrm{CF}_{3}\right)_{2}$ COFs. A TpBD COF cell was built in Materials Studio software ${ }^{4}$ by using the reported parameters (space group P6/m, $a=b=$ $\left.30.5 \AA, c=3.4 \AA, \alpha=6=90^{\circ}, \nu=120^{\circ}\right) .{ }^{5}$ The obtained structure was modified to get TpBD $-\left(\mathrm{NO}_{2}\right)_{2}$ and TpBD- $\left(\mathrm{NH}_{2}\right)_{2}$ COF supercells. The structure of TpBD- $\left(\mathrm{CF}_{3}\right)_{2}$ was previously described. ${ }^{2}$ The cell parameters are $a=b=28.67 \AA, c=4.25 \AA, \alpha=6=90^{\circ}, \gamma=120^{\circ}$; space group is P6. For purposes of molecular simulations a 3D periodic box with the dimensions of $a \times a \times c$ was built, with the $c$ dimension about $80 \AA$. The box contained $6-8$ COF layers simulating a surface with a thickness of about $28 \AA$ and a part of the COF pore (one $4 a \times 4 a \times c$ 3D periodic box would contain one entire COF pore). To describe the structure of the COF-toxin system, it is necessary to get a structure model ideally giving the lowest value of the adsorption energy. For this purpose, 4 types of structure models were built: COF-water-toxin model, COF-water model, water model, and water-toxin model. All 4 structure models contained about 1800 water molecules to keep the density of $1000 \mathrm{~kg} \mathrm{~m}^{-3}$; the molar volumes of individual components in the models were kept constant. The molecular simulations were carried out as detailed in the following.

COF-water-toxin models

At first, the calculations were carried out in vacuum to find the binding sites of the toxins on the COF structure. A set of initial models with different orientations of one toxin molecule placed above the COF surface was built. After a geometry optimization of the starting models 1-2 ns quench dynamics simulation in an NVT statistical ensemble ( $\mathrm{N}$ - constant number of atoms, V - constant volume, $\mathrm{T}$ constant temperature) at $298 \mathrm{~K}$ was done in Materials Studio software. Thereafter, the models with the most different geometry (a set of 3-5 models) were selected for subsequent calculations. The free volume of the periodic box was filled with water molecules and the geometry of the models was optimized in Materials Studio. At this stage all atomic positions in the structure except of water molecules were kept fixed. After the geometry optimization a short molecular dynamics simulation ( $\leq 30 \mathrm{ps)}$ was carried out to preequilibrate the positions of water molecules in the simulation box. This simulation was repeated again, this time with free atomic positions of the toxin and water molecules. Thereafter, molecular dynamics simulations were carried out in the Lammps simulation package ${ }^{6}$ with all atomic positions variable except those within the COF structure.

\section{COF-water models, water models, and water-toxin models}

In all cases, 3 independent structure models with different starting configurations were built and the simulation strategy was very similar as in the COF-water-toxin models. In the COF-water models the atomic positions of the COF were fixed and the positions of water molecules were variable during the simulations. In the water-toxin models all atomic positions were variable except of the geometry optimization of initial models and short molecular dynamic runs carried out in Materials Studio, where all the atomic positions of the toxin molecules were kept fixed. Then, the pre-equilibrated models were used in the Lammps simulation package.

\section{Molecular simulations conditions in Lammps}

At first, a few hundred thousand steps of the dynamics simulation at $300 \mathrm{~K}$ were performed, and then the system was heated up to $500 \mathrm{~K}$ for 1-2 ns. After the system was cooled down, $1 \mathrm{~ns}$ 
molecular dynamics simulation at $298 \mathrm{~K}$ followed. Then, $5 \mathrm{~ns}$ blocks of molecular dynamics simulations at $298 \mathrm{~K}$ were repeated until the convergence of the total energy value of the structure models was reached. The snapshots were collected every 2000 steps. The molecular simulations were carried out in an NVT statistical ensemble. In all cases (including the geometry optimization and molecular dynamics in Materials Studio), pcff interface forcefield ${ }^{7}$ was employed in the simulations, the calculations were done in the space group P1. One simulation step was $1 \mathrm{fs}$, the atomic charges of the COF structure and the parameters for water molecules were incorporated int o pcff force field from the Compass forcefield. ${ }^{8}$ Temperature was controlled by Nosé-Hoover thermostat. Electrostatic interactions were calculated by the PPPM method with the accuracy of $10^{-6} \mathrm{kcal} \mathrm{mol}^{-1}$ and van der Waals interactions were calculated by using Lennard-Jones potential with a cut-off of $12 \AA$.

\section{Adsorption energycalculations}

The individual trajectories of the molecular dynamics simulations for all types of structure models exhibited slight deviations $( \pm 0.1 \mathrm{~K}$ ) of the target average temperature of $298 \mathrm{~K}$. To obtain comparable results, the average value of the total energy for each trajectory was adjusted to $298 \mathrm{~K}$ by using the heat capacity of the system calculated during the simulations. In case of water models, water-toxin models and COF-water models, the uncertainty of the average value of the total energy was about $\pm 0.5 \mathrm{kcal} \mathrm{mol}^{-1}$. In case of COF-water-toxin models the situation was somewhat different, i.e. the models with different geometries exhibited different average values of the total energy. The convergence criterion for each trajectory was reached when the difference between the average values of two successive 5 ns blocks (or between two consecutive $10 \mathrm{~ns}$ and $5 \mathrm{~ns}$ blocks) was less than $1 \mathrm{kcal} \mathrm{mol}^{-1}$. The structure models with the lowest value of average total energy were involved in the adsorption energy $\left(\Delta E_{\text {ads }}\right)$ calculation presented in Table 1:9

$\Delta E_{\text {ads }}=E_{\text {COF-water-toxin }}-E_{\text {water-toxin }}+E_{\text {water }}-E_{\text {COF-water }}$

Shift of the COF layers

To estimate the relative position of two adjacent layers in the investigated models we built a supercell containing two COF layers and one entire COF pore. The position of the layers was estimated by searching for the global minimum of the interaction energy by a systematic shift of one layer with $0.5 \AA$ steps along $x$ and $y$ axes direction. In case of TpBD- $\left(\mathrm{NO}_{2}\right)_{2}$ the global minimum of the interaction energy was reached for $x=y=2 \AA$. In case of TpBD- $\left(\mathrm{NH}_{2}\right)_{2}$ the relative position of the layers exhibited certain variability with very similar values to the value of the global minimum of the interaction energy. To keep the structure consistency with TpBD- $\left(\mathrm{NO}_{2}\right)_{2}$ we adopted the model with the same layer shift. In case of TpBD- $\left(\mathrm{CF}_{3}\right)_{2}$ the lowest value of the interaction energy was obtained for an eclipsed arrangement due to non-planarity of the COF layers stemming from the presence of $\mathrm{CF}_{3}$ substituents. 


\section{Powder X-ray diffraction (PXRD)}

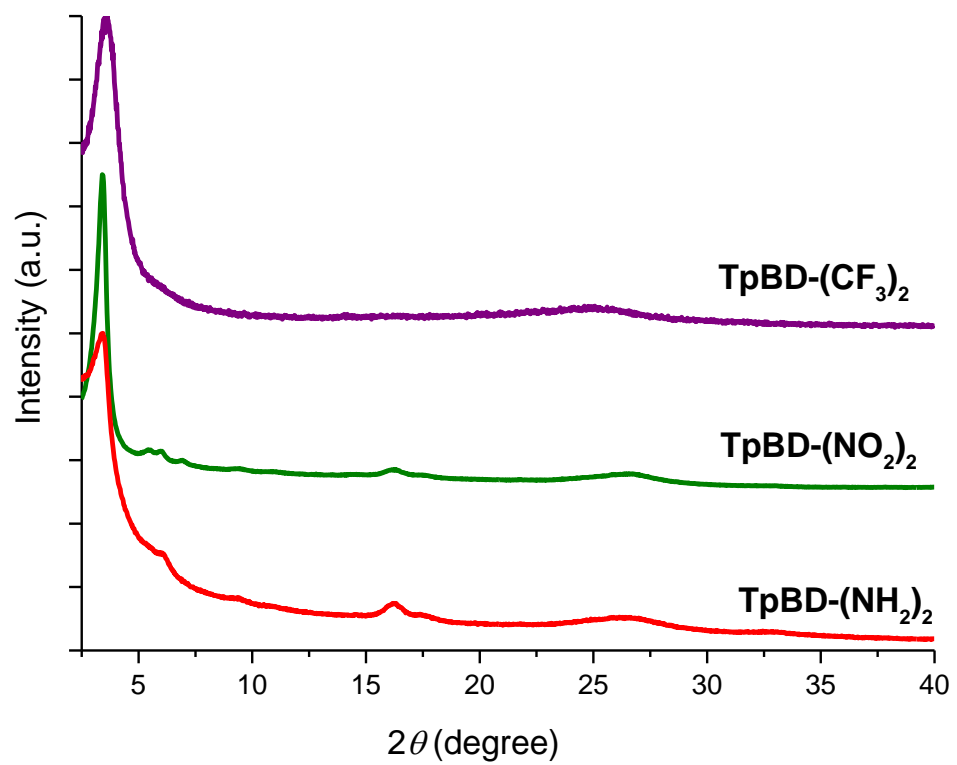

Figure S1. Powder X-ray diffraction pattern of TpBD- $\left(\mathrm{CF}_{3}\right)_{2}, \mathrm{TpBD}-\left(\mathrm{NO}_{2}\right)_{2}$, and TpBD- $\left(\mathrm{NH}_{2}\right)_{2}$.

The PXRD pattern of TpBD- $\left(\mathrm{CF}_{3}\right)_{2}$ shows main reflections at about $2 \theta=3.5^{\circ}, 5.9^{\circ}$, and $25^{\circ}$, as reported for this COF. ${ }^{2}$ The PXRD pattern of TpBD- $\left(\mathrm{NO}_{2}\right)_{2}$ shows the first intensive reflection at $2 \theta=3.4^{\circ}$ and further reflections at $5.5^{\circ}, 6.9^{\circ}$, and $26^{\circ}$, in good agreement with the reported values. ${ }^{3}$ PXRD pattern of TpBD- $\left(\mathrm{NH}_{2}\right)_{2}$ shows an intensive reflection at $3.4^{\circ}$, as reported in the literature. ${ }^{3}$ 


\section{5. $\mathrm{N}_{2}$ Physisorption}

$\operatorname{TpBD}-\left(\mathrm{CF}_{3}\right)_{2}$

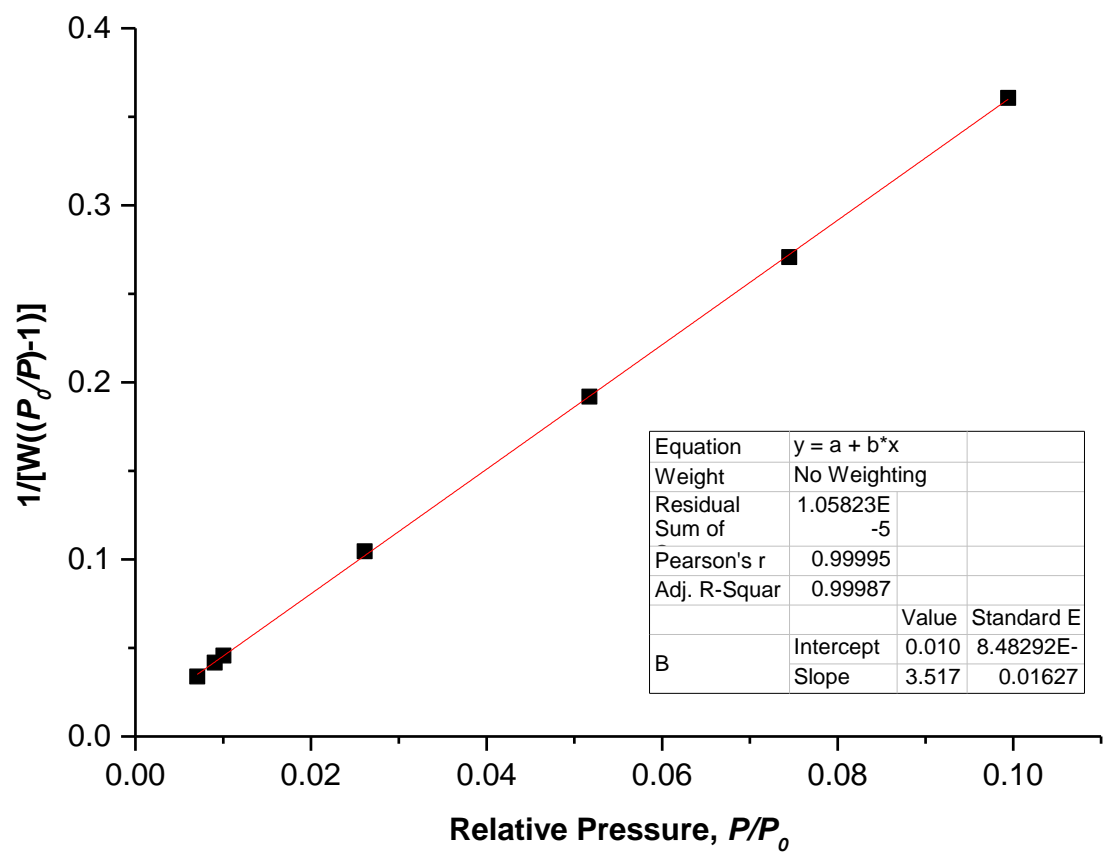

Figure S2. Multi-point BET plot and linear fit.

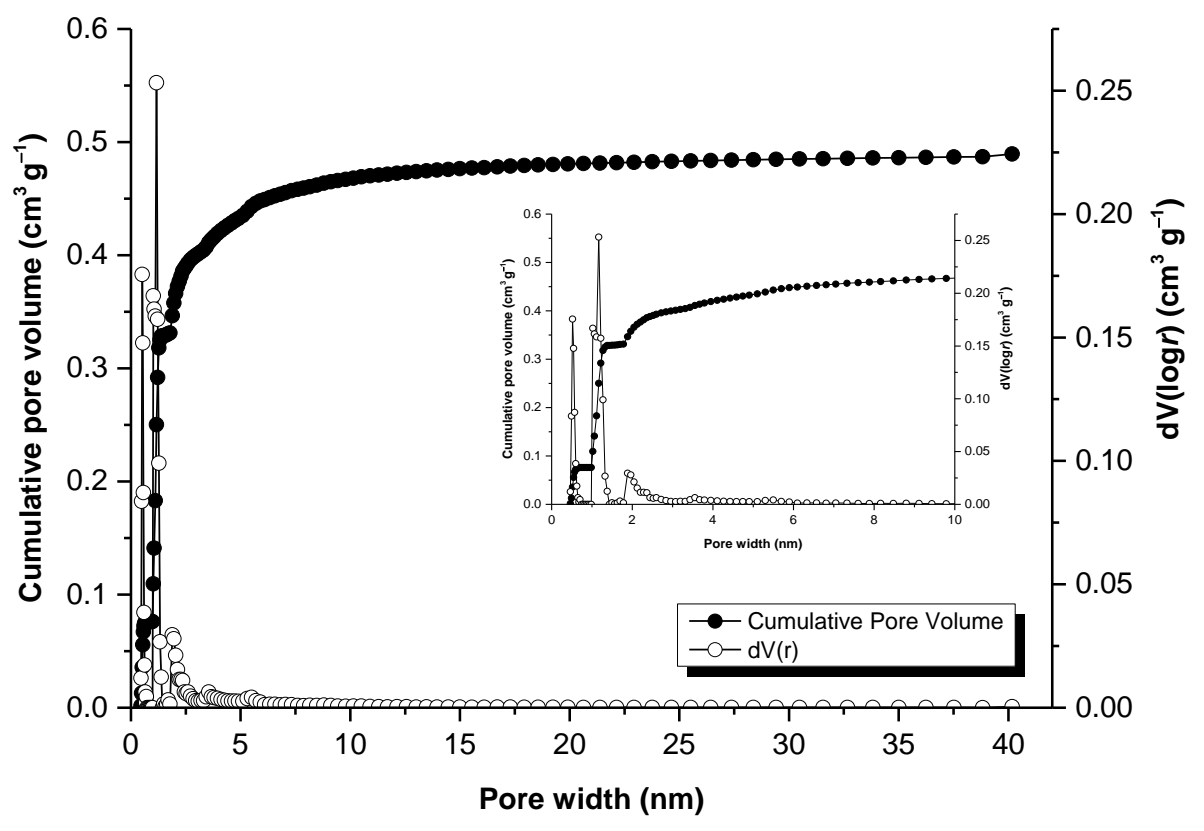

Figure S3. Pore size distribution (hollow spheres) and cumulative pore volume (filled spheres) profiles. 
$\operatorname{TpBD}-\left(\mathrm{NO}_{2}\right)_{2}$

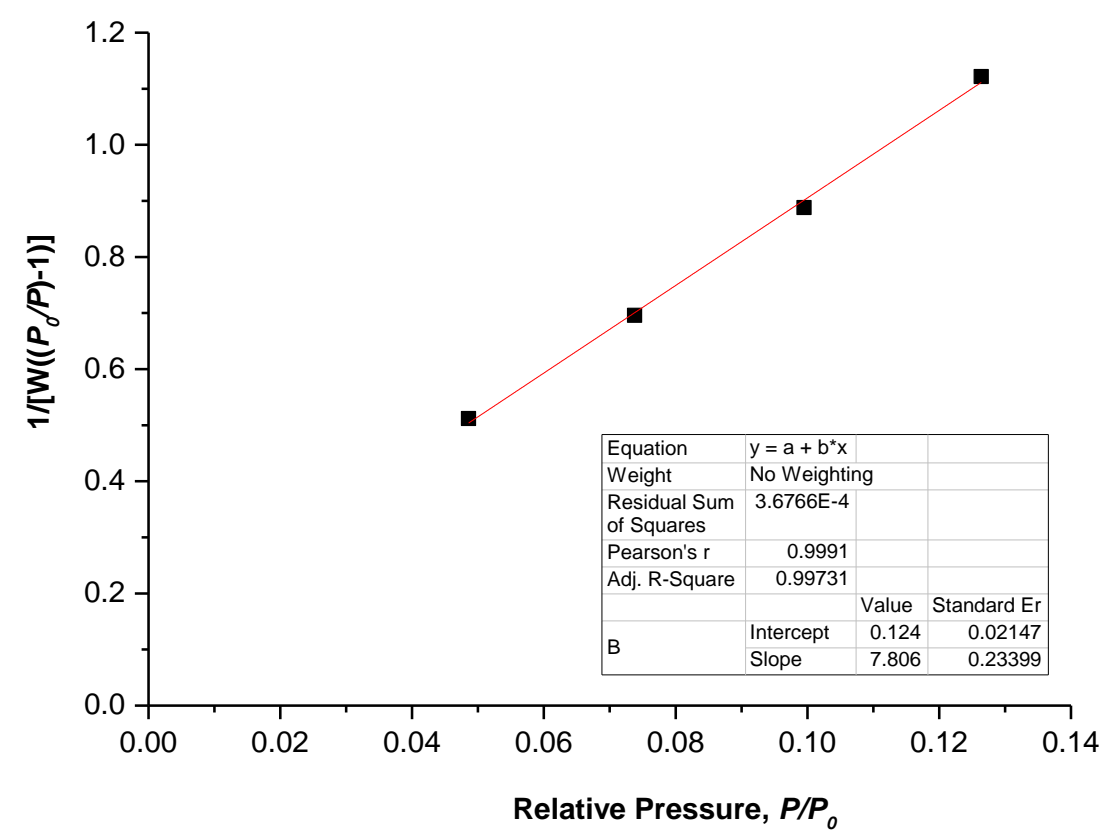

Figure S4. Multi-point BET plot and linear fit.

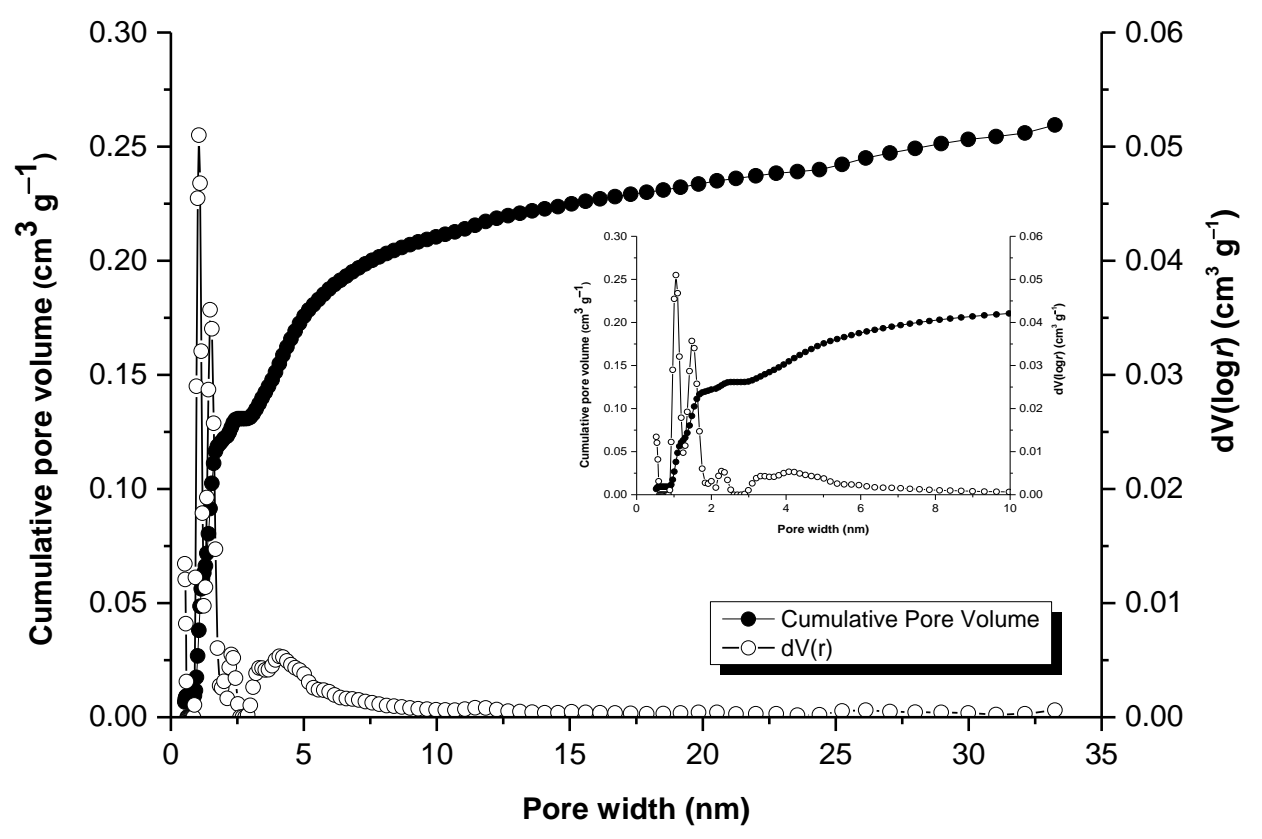

Figure S5. Pore size distribution (hollow spheres) and cumulative pore volume (filled spheres) profiles. 
$\operatorname{TpBD}-\left(\mathrm{NH}_{2}\right)_{2}$

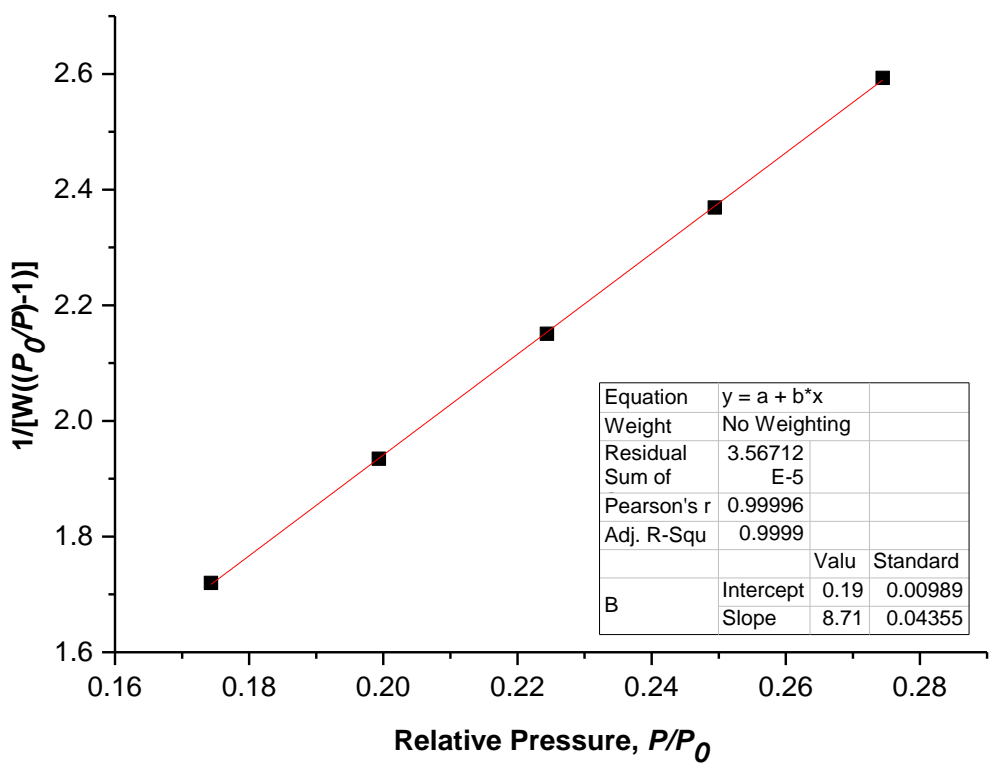

Figure S6. Multi-point BET plot and linear fit.

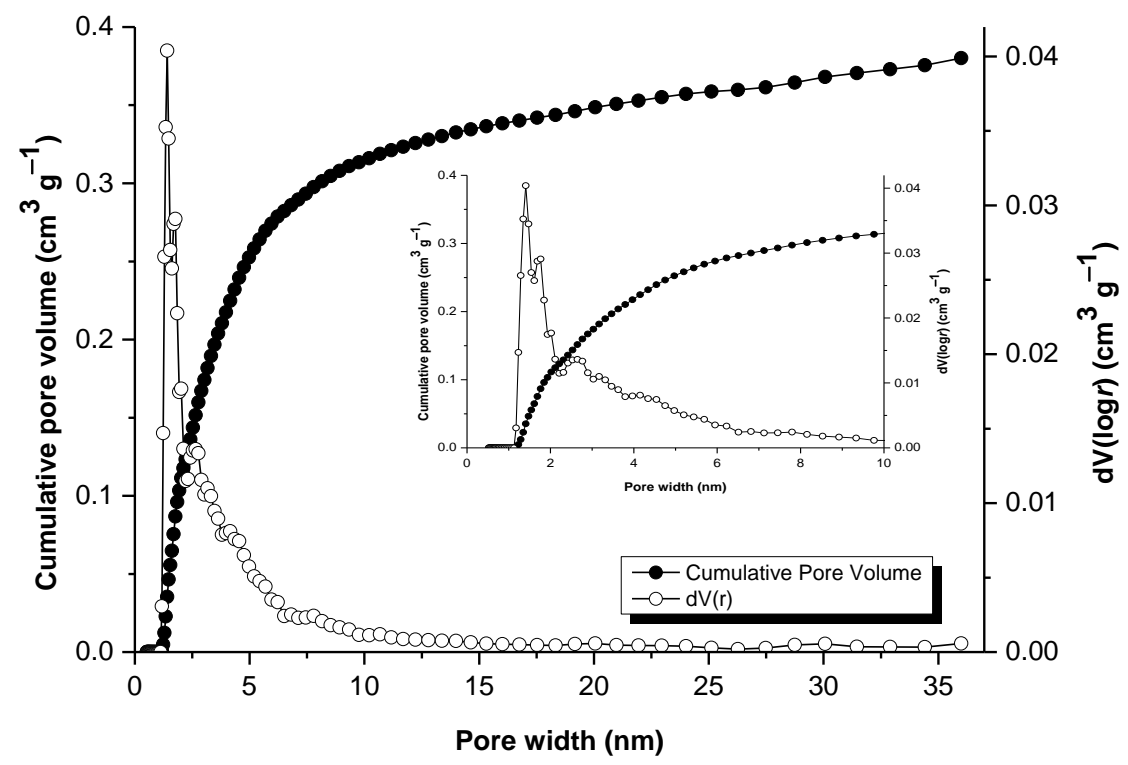

Figure S7. Pore size distribution (hollow spheres) and cumulative pore volume (filled spheres) profiles. 


\section{Fourier-transform infrared (FT-IR)}

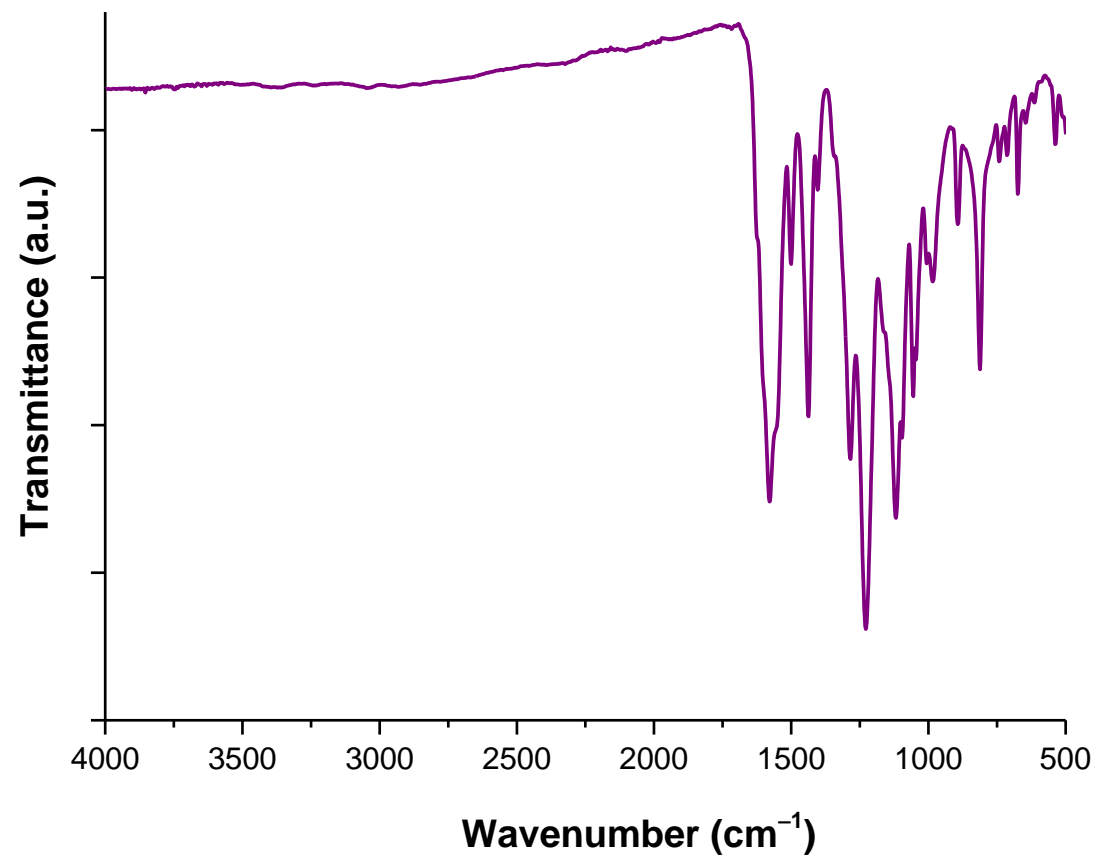

Figure S8. FT-IR spectrum of TpBD- $\left(\mathrm{CF}_{3}\right)_{2}$.

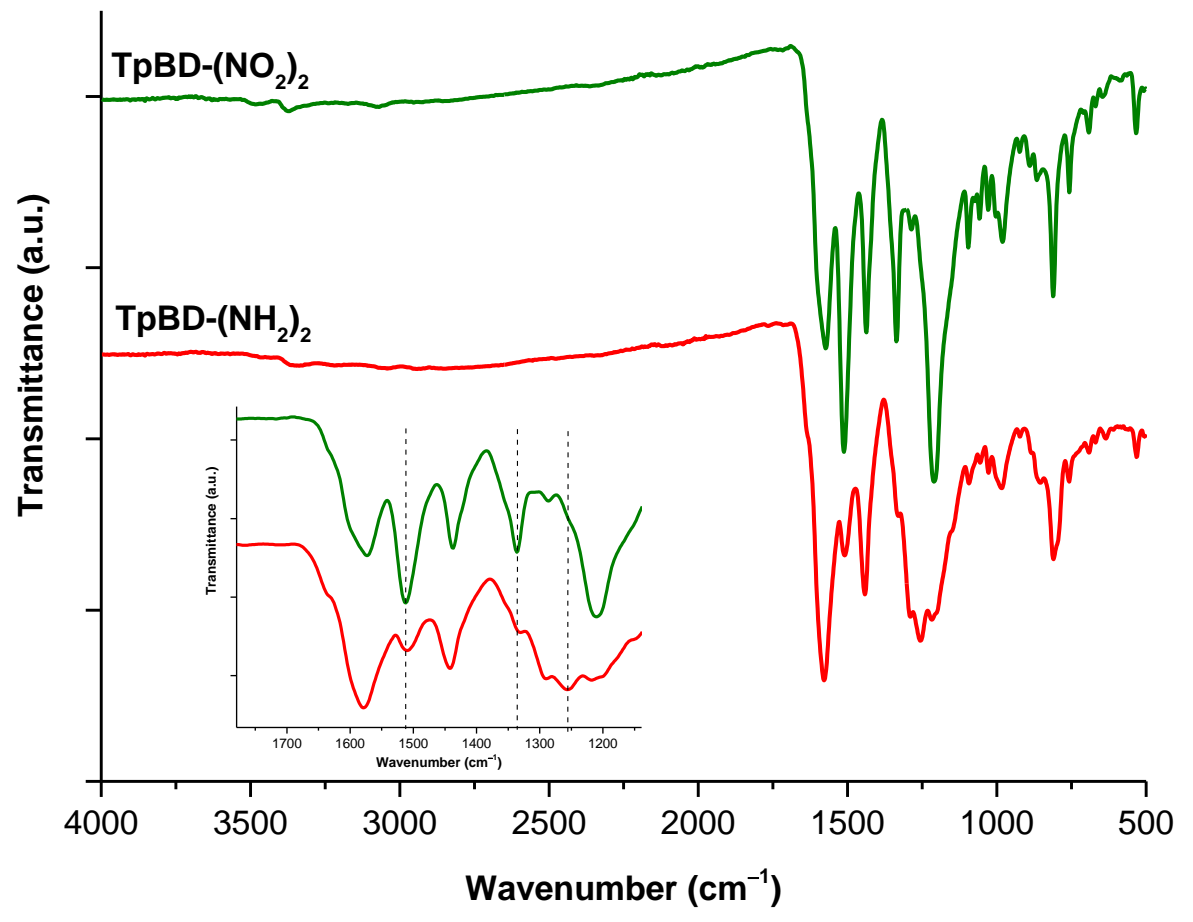

Figure S9. FT-IR spectrum of TpBD- $\left(\mathrm{NO}_{2}\right)_{2}$ and TpBD- $\left(\mathrm{NH}_{2}\right)_{2}$. 
7. Thermogravimetric analysis (TGA)

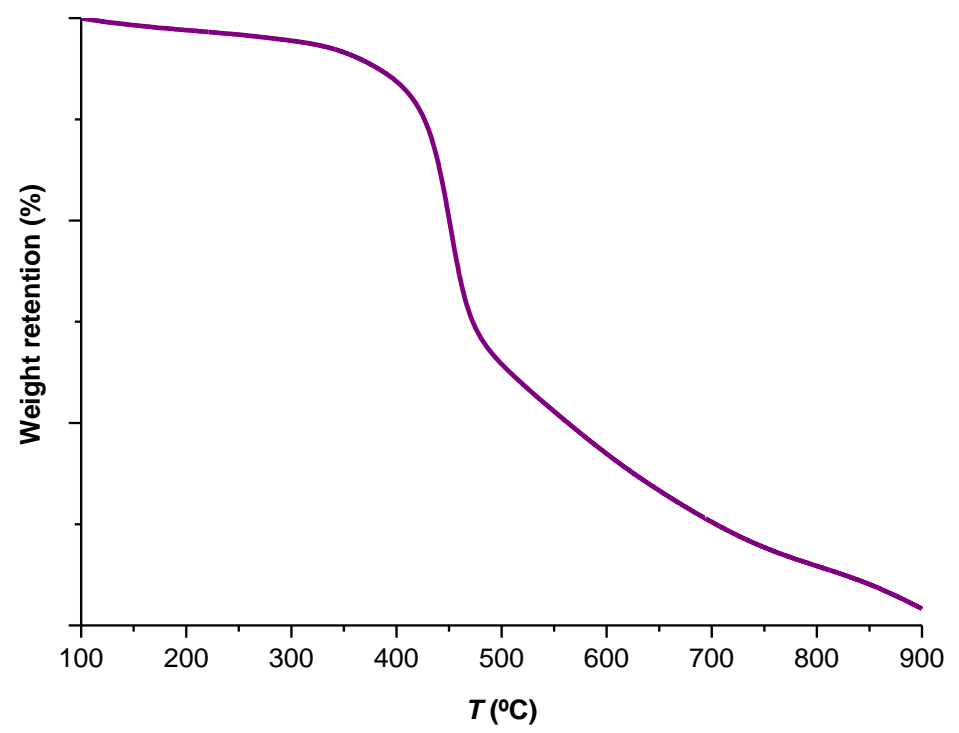

Figure S10. TGA data of TpBD- $\left(\mathrm{CF}_{3}\right)_{2}$.

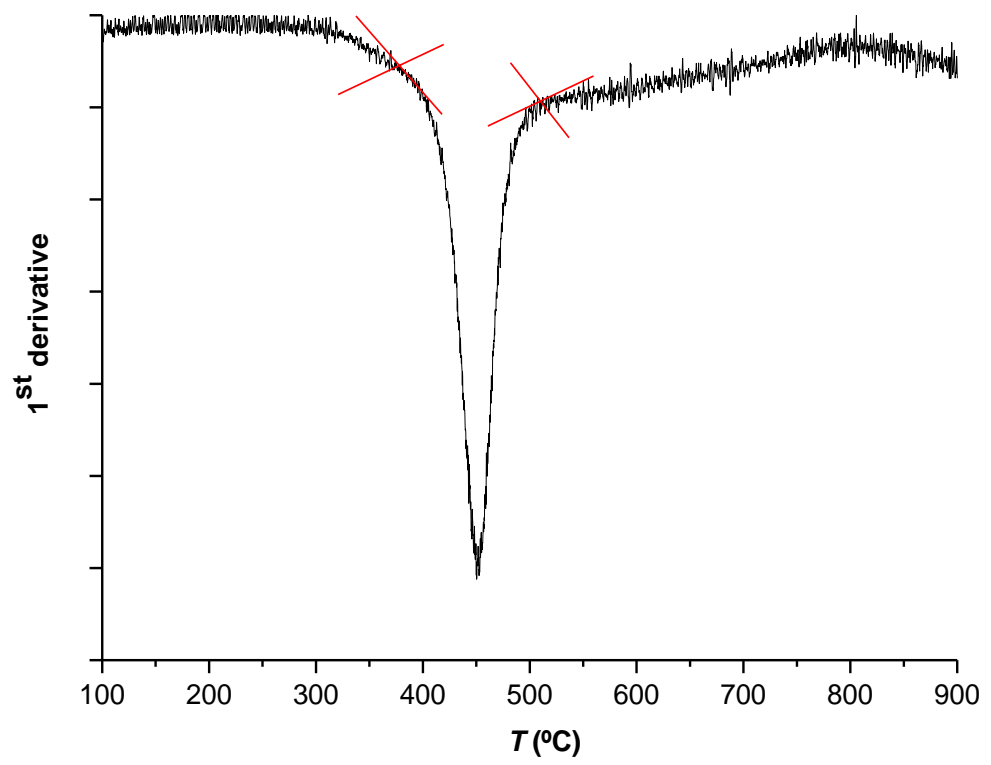

Figure S11. $1^{\text {st }}$ Derivative of the TGA data of TpBD- $\left(\mathrm{CF}_{3}\right)_{2}$. 


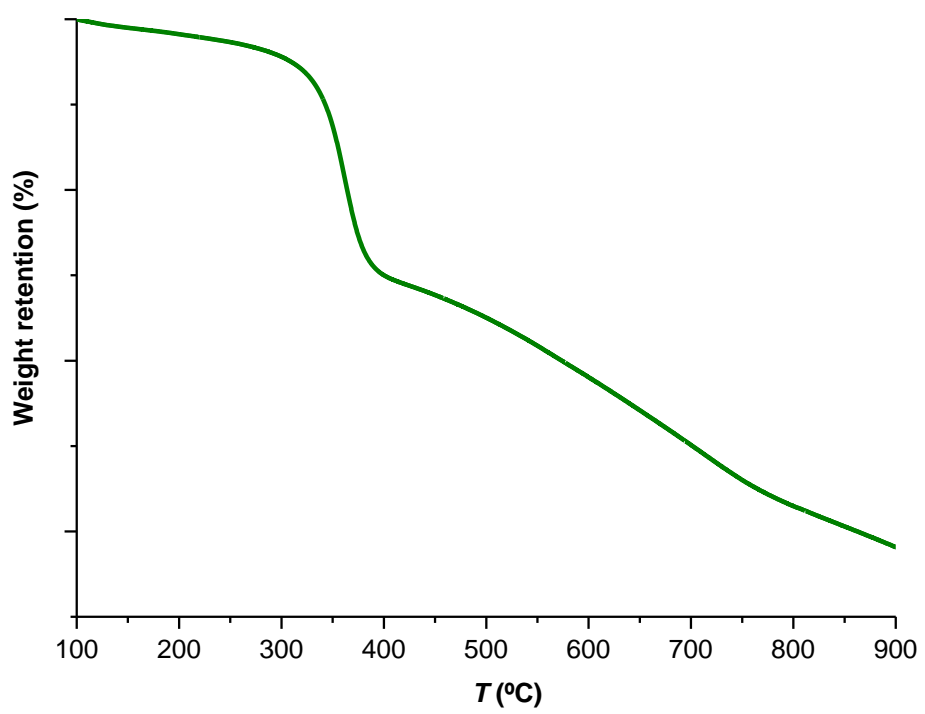

Figure S12. TGA data of TpBD- $\left(\mathrm{NO}_{2}\right)_{2}$.

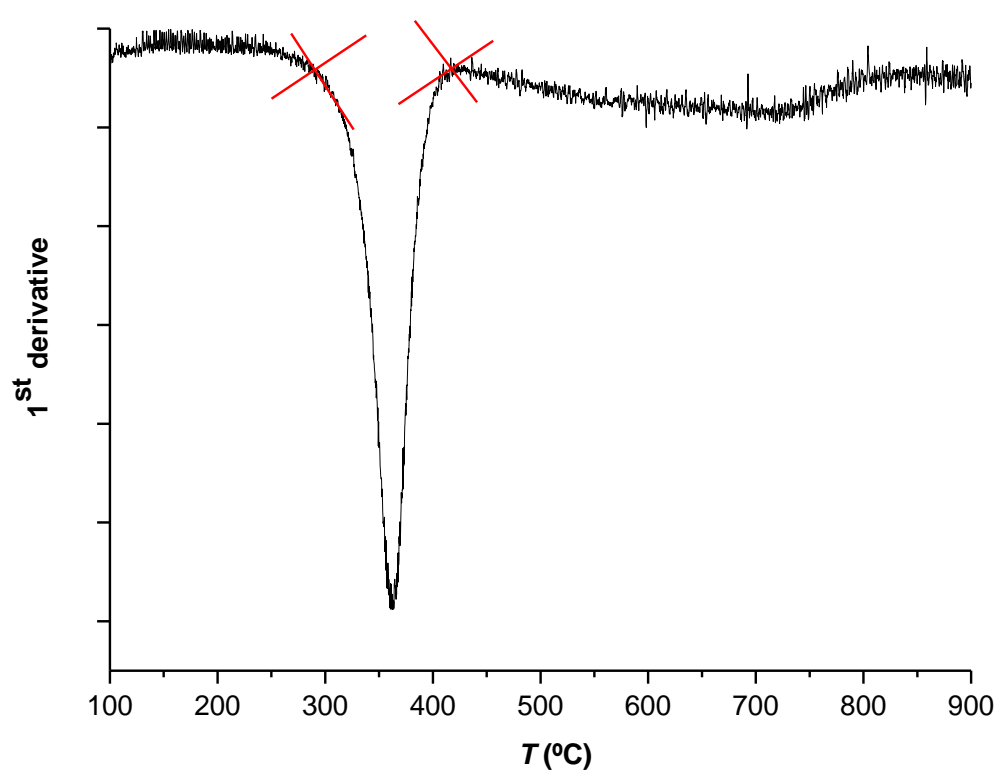

Figure S13. $1^{\text {st }}$ Derivative of the TGA data of TpBD- $\left(\mathrm{NO}_{2}\right)_{2}$. 


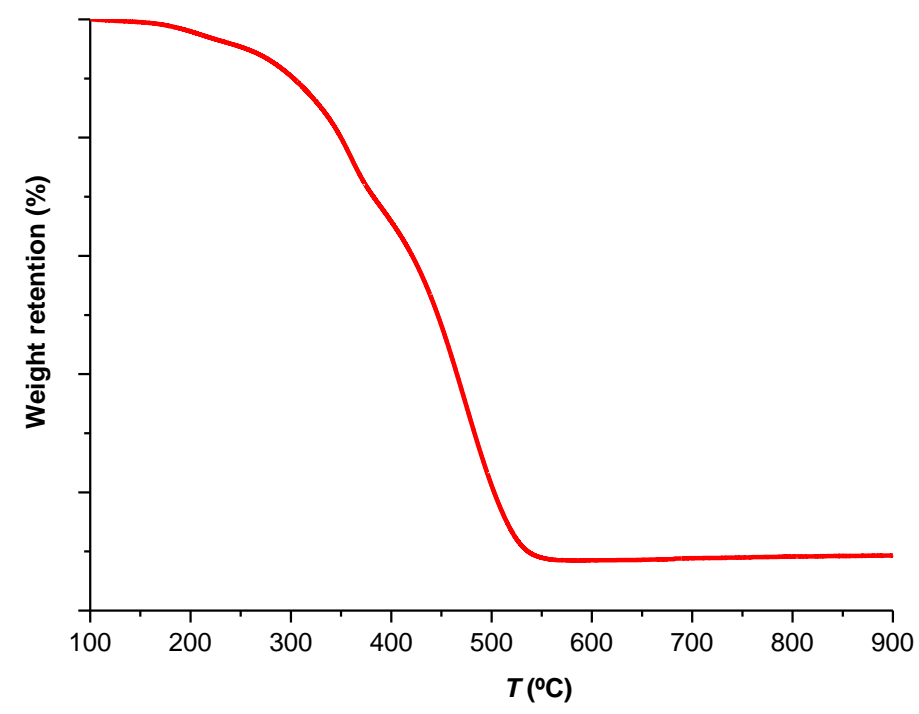

Figure S14. TGA data of TpBD- $\left(\mathrm{NH}_{2}\right)_{2}$.

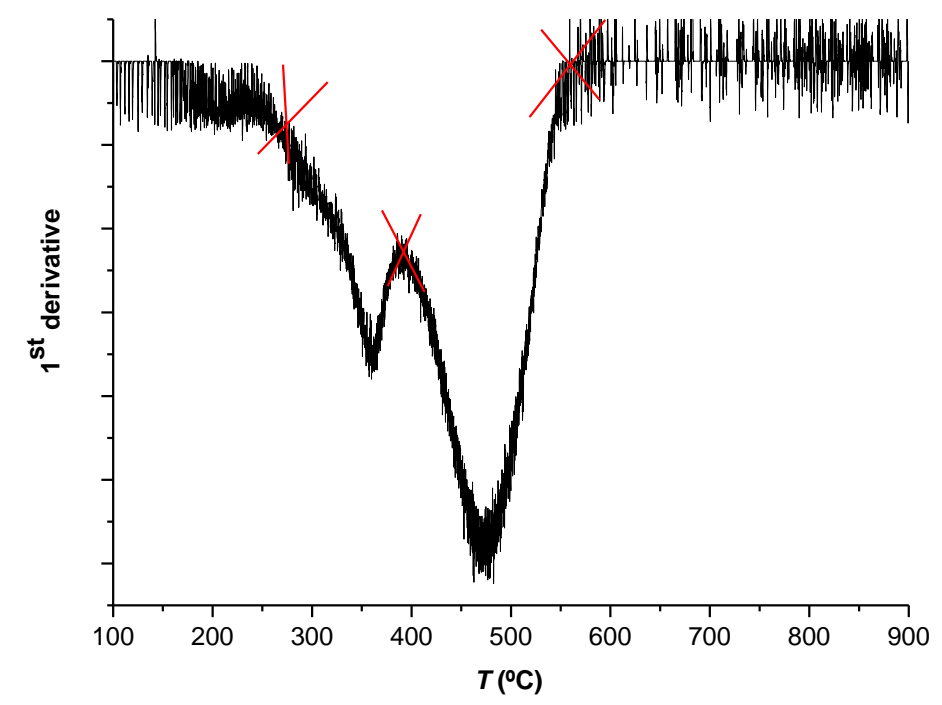

Figure S15. $1^{\text {st }}$ Derivative of the TGA data of TpBD- $\left(\mathrm{NH}_{2}\right)_{2}$. 


\section{Contact angle}

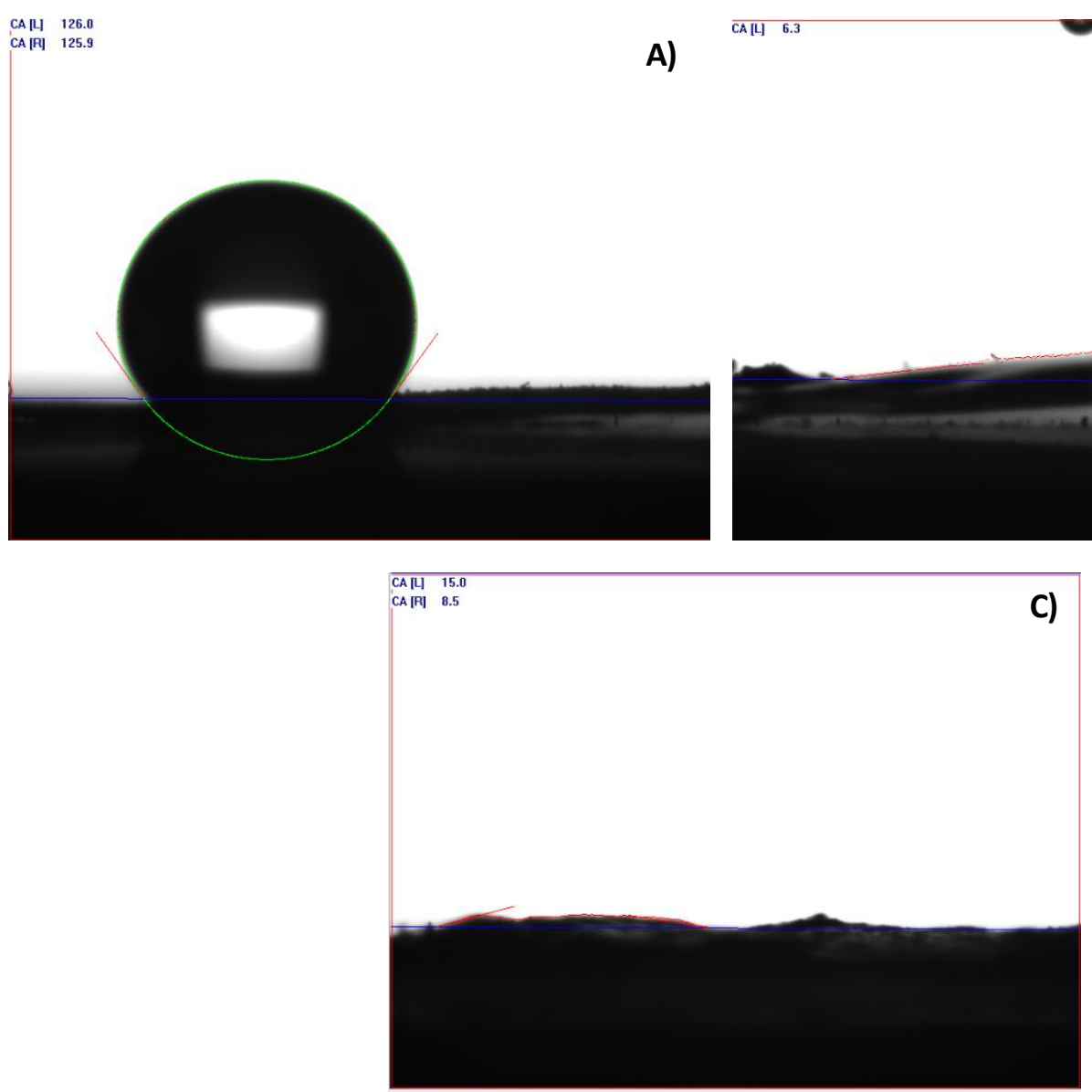

Figure S16. TpBD- $\left(\mathrm{CF}_{3}\right)_{2}(\mathrm{~A})$ shows a contact angle of $126^{\circ}$, while in the case of TpBD- $\left(\mathrm{NH}_{2}\right)_{2}(\mathrm{~B})$ and TpBD- $\left(\mathrm{NO}_{2}\right)_{2}$ (C) contact angles of $6.3^{\circ}$ and $15^{\circ}$ were observed, respectively. 


\section{Scanning electron microscopy (SEM)}

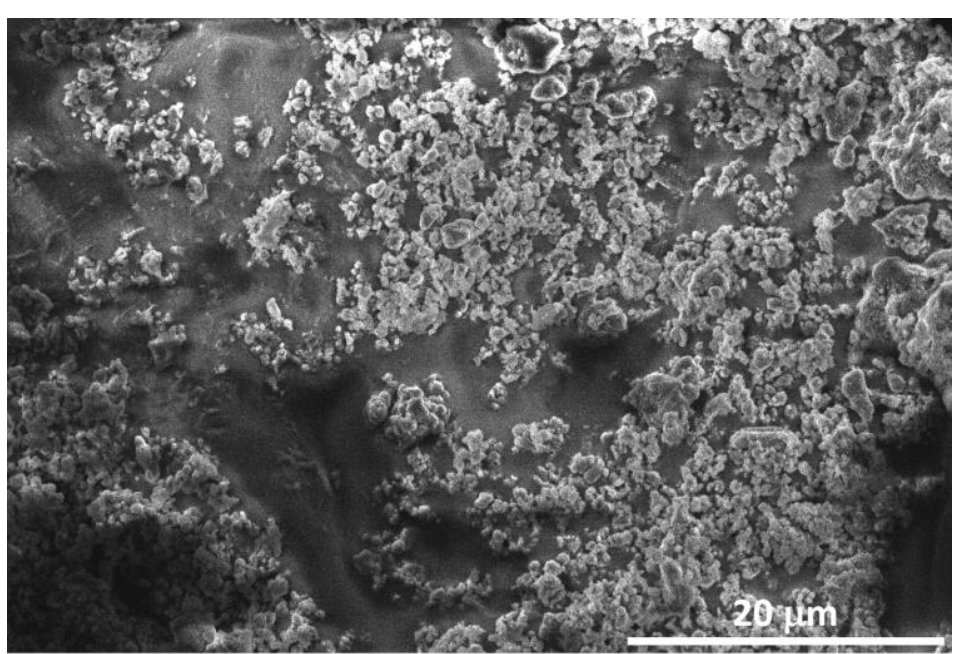

Figure S17. SEM image of TpBD- $\left(\mathrm{CF}_{3}\right)_{2}$.

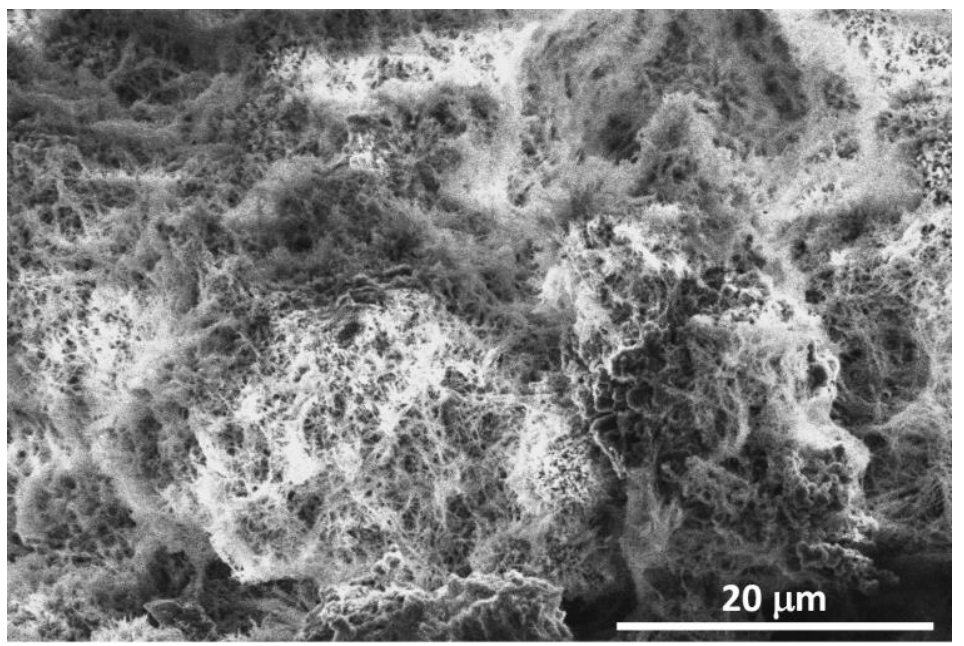

Figure S18. SEM image of TpBD- $\left(\mathrm{NO}_{2}\right)_{2}$.

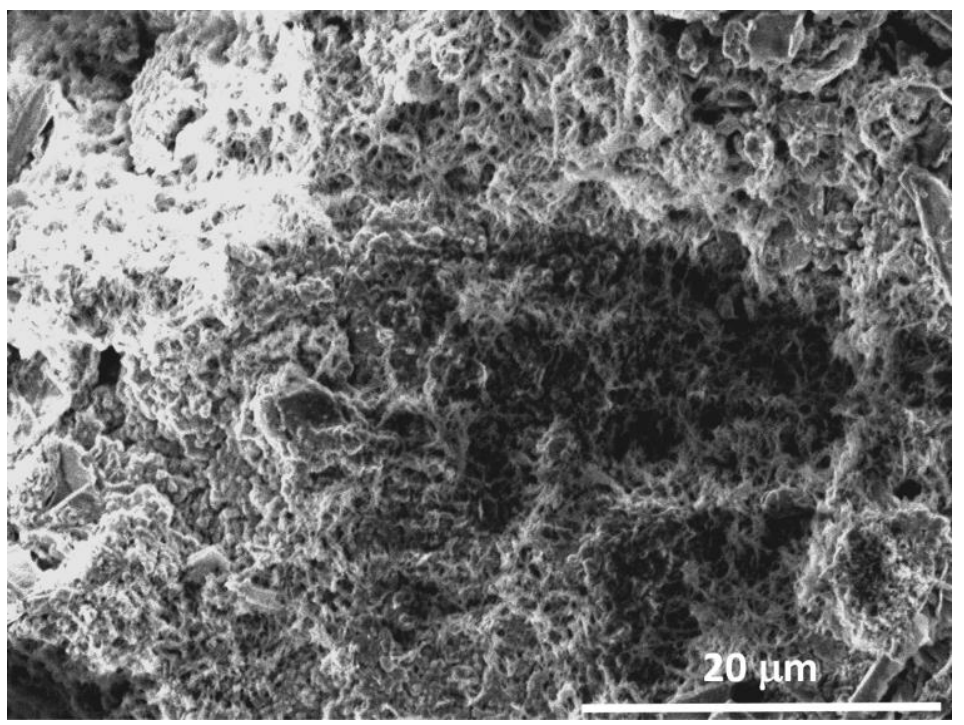

Figure S19. SEM image of TpBD- $\left(\mathrm{NH}_{2}\right)_{2}$. 


\section{Microcystin adsorption process}

\subsection{Microcystin quantification}

Aqueous reaction buffer consisted of $20 \mathrm{mM}$ Tris- $\mathrm{HCl}, 5 \mathrm{mM} \mathrm{MgCl}, 1 \mathrm{mM} \mathrm{MnCl}, 0.1 \%(\mathrm{v} / \mathrm{v})$ 2-mercaptoethanol, and $1 \mathrm{mg} \mathrm{mL}-1$ bovine serum albumin (BSA) adjusted to $\mathrm{pH}=8$. DIFMUP stock solution was prepared at $40 \mathrm{mM}$ in a solution of $50 \mathrm{mM}$ Tris- $\mathrm{HCl}$ at $\mathrm{pH}=8$. PP1 was

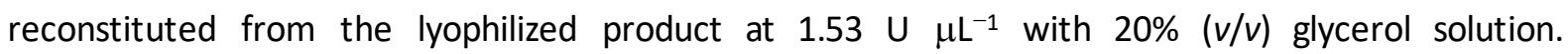
$\mathrm{MC}$ stock solutions were prepared at $1 \mathrm{mM}$ with ultrapure water.

Separated calibration curves were used for each quantification experiment of the different microcystins, and performed in the same microplate as the rest of the samples. Microcystin standard solutions for the calibration curves were prepared in the corresponding solvent, ultrapure water for the quantification of the supernatants from the adsorption test and propan-2-ol for the quantification of the supernatants from the desorption assay. The PP1 inhibition assays were performed in a flat-bottom opaque 96-well microplates with a final volume of $200 \mu \mathrm{L}$ in each well. More in detail, $10 \mu \mathrm{L}$ of an intermediate solution of PP1 $\left(0.02 \mathrm{U} \mu \mathrm{L}^{-1}\right)$, prepared by dilution of the stock solution with aqueous buffer, was added to the reaction wells containing $165 \mu \mathrm{L}$ of reaction buffer. Then, $20 \mu \mathrm{L}$ of the corresponding solution of microcystin calibration curve, solvent (blank), or supernatant samples obtained from the adsorption/desorption assays were added to the wells of microplate. Then, the microplate was incubated for $30 \mathrm{~min}$ under constant shaking of $500 \mathrm{rpm}$ at $37{ }^{\circ} \mathrm{C}$ for a maximum enzymatic inhibition. Afterward, $5 \mu \mathrm{L}$ of $8 \mathrm{mM}$ DIFMUP solution, prepared by dilution of the stock solution with aqueous buffer, was added to the wells. Next, the microplate was again incubated under constant shaking of $500 \mathrm{rpm}$ at $37{ }^{\circ} \mathrm{C}$ for $2 \mathrm{~h}$. Fluorescence intensity was measured (excitation wavelength $315 \mathrm{~nm}$, emission wavelength $470 \mathrm{~nm}$ ) in a BioTek Synergy H1 microplate reader. Analytical calculations were provided in duplicates for each experiment.

\subsection{Calibration curves for MC quantification}

Calibration curves were prepared using the software Origin9 ${ }^{\circledR}$, plotting the known concentration of serial dilutions against their corresponding fluorescence at $470 \mathrm{~nm}$. Then, a non-linear pharmacology dose-response fitting was applied. Calibration curves were prepared using the corresponding solvent, ultrapure water or propan-2-ol, as the solvent for calibration standard solutions. Examples of calibration curves made for each microcystin with the used solvents are presented below. The calibration curves represent the average fluorescent values of three different experiments. The error bars were calculated as standard deviation (SD). 


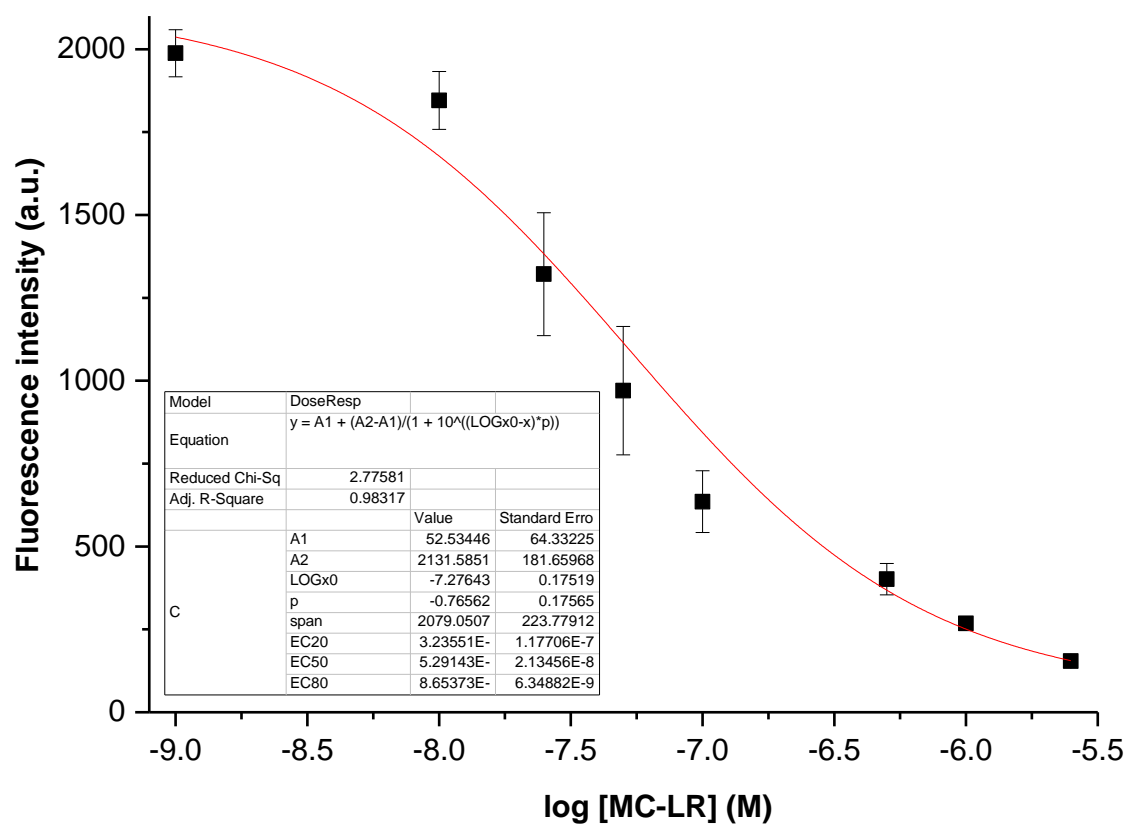

Figure S20. MC-LR calibration curve in ultrapure water.

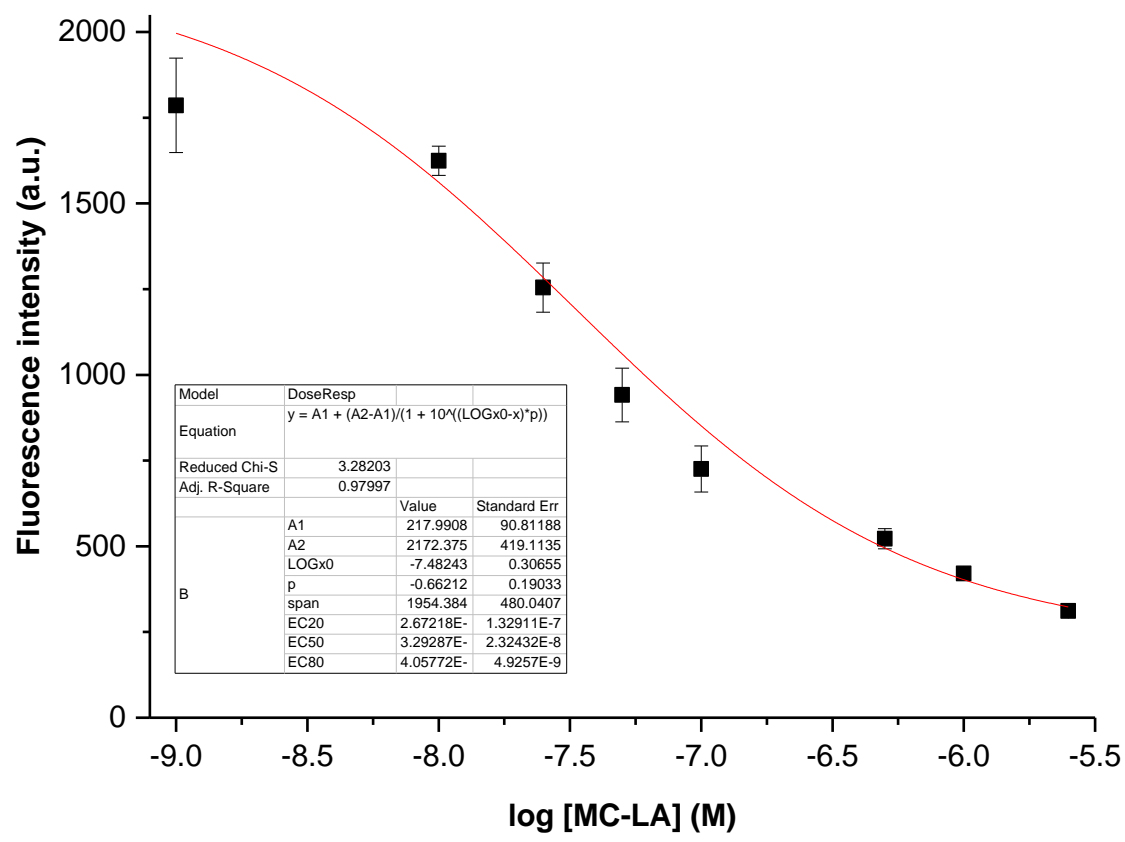

Figure S21. MC-LA calibration curve in ultrapure water. 


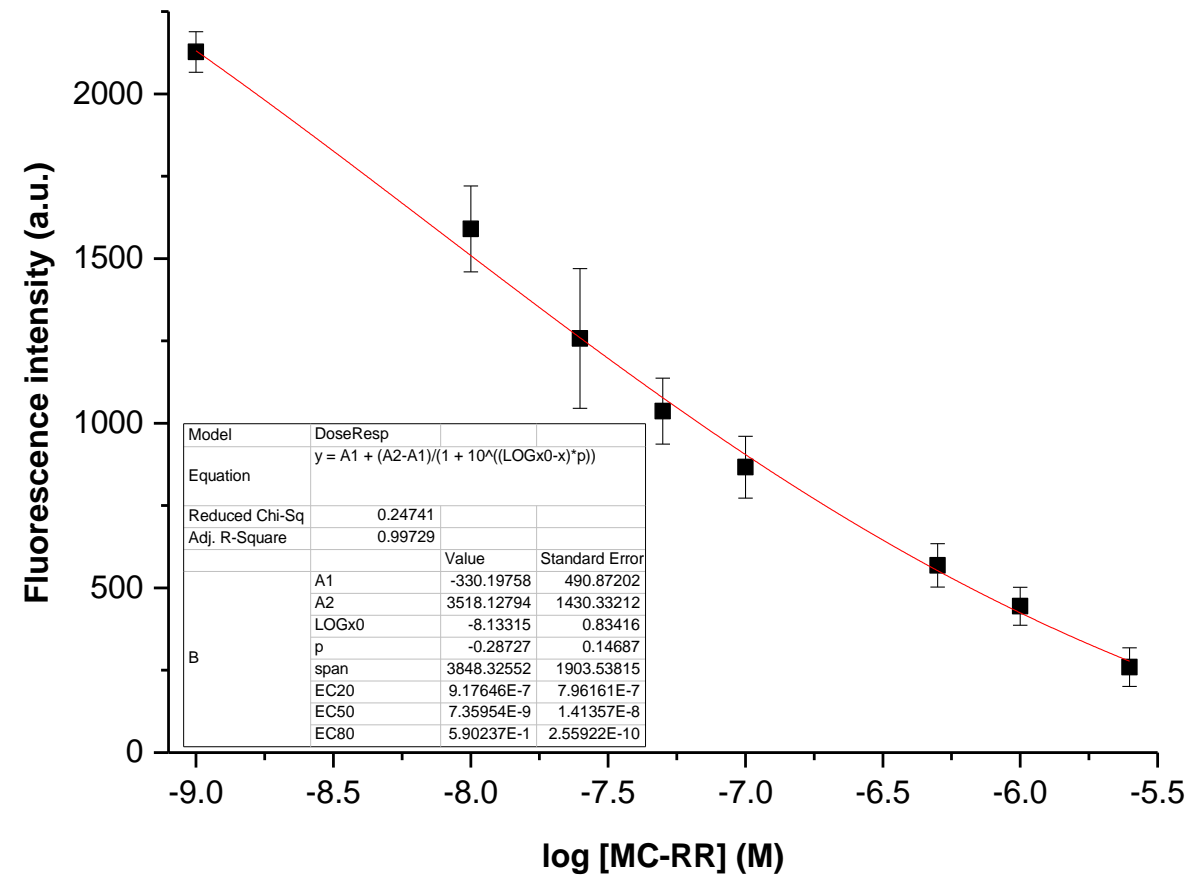

Figure S22. MC-RR calibration curve in ultrapure water.

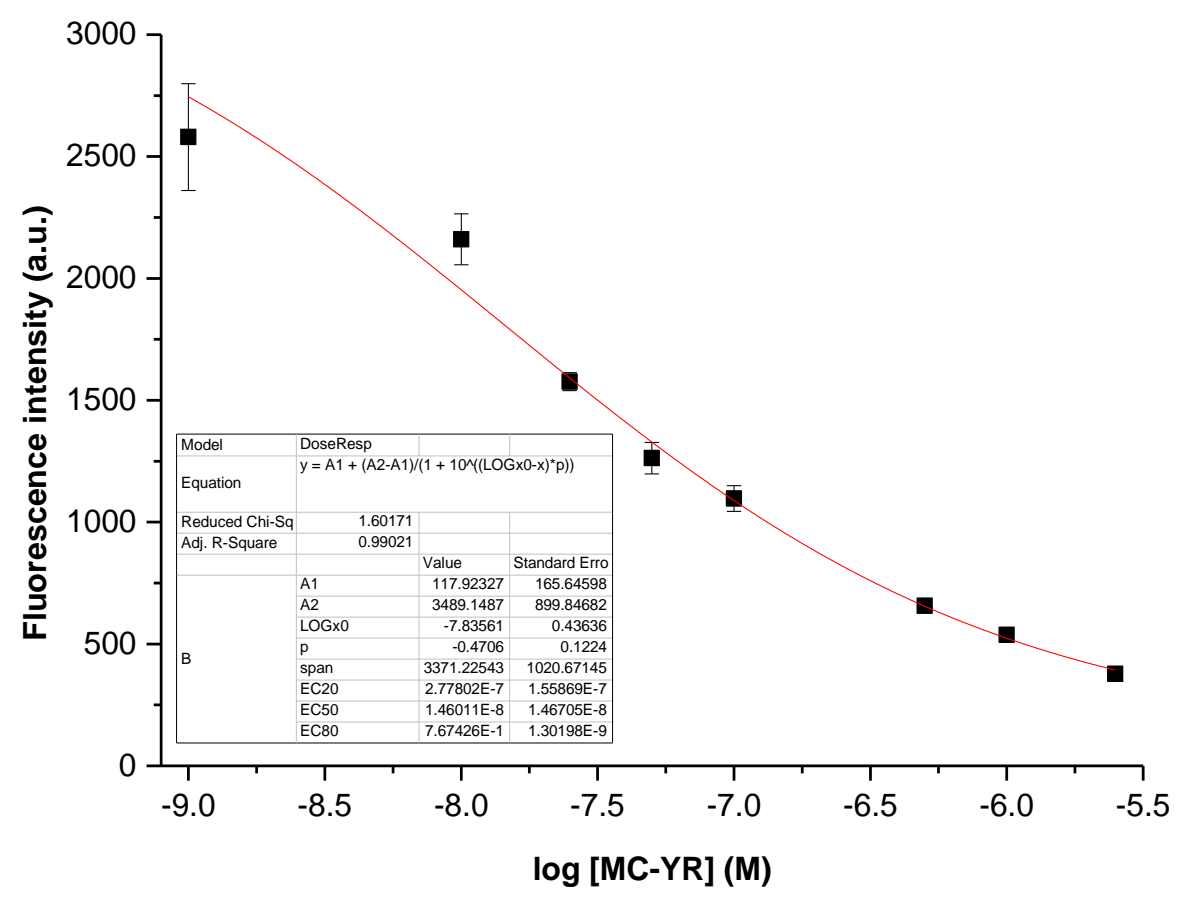

Figure S23. MC-YR calibration curve in ultrapure water. 


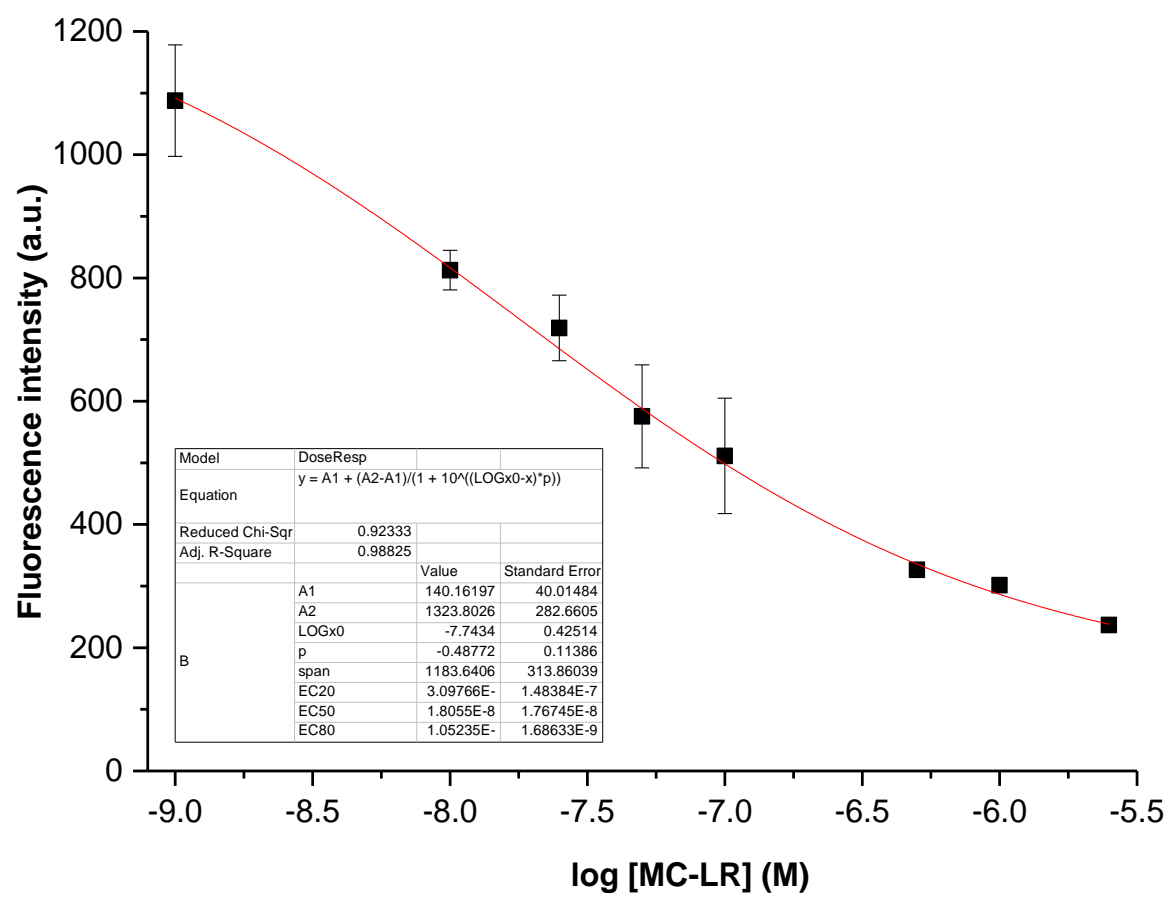

Figure S24. MC-LR calibration curve in 2-propanol.

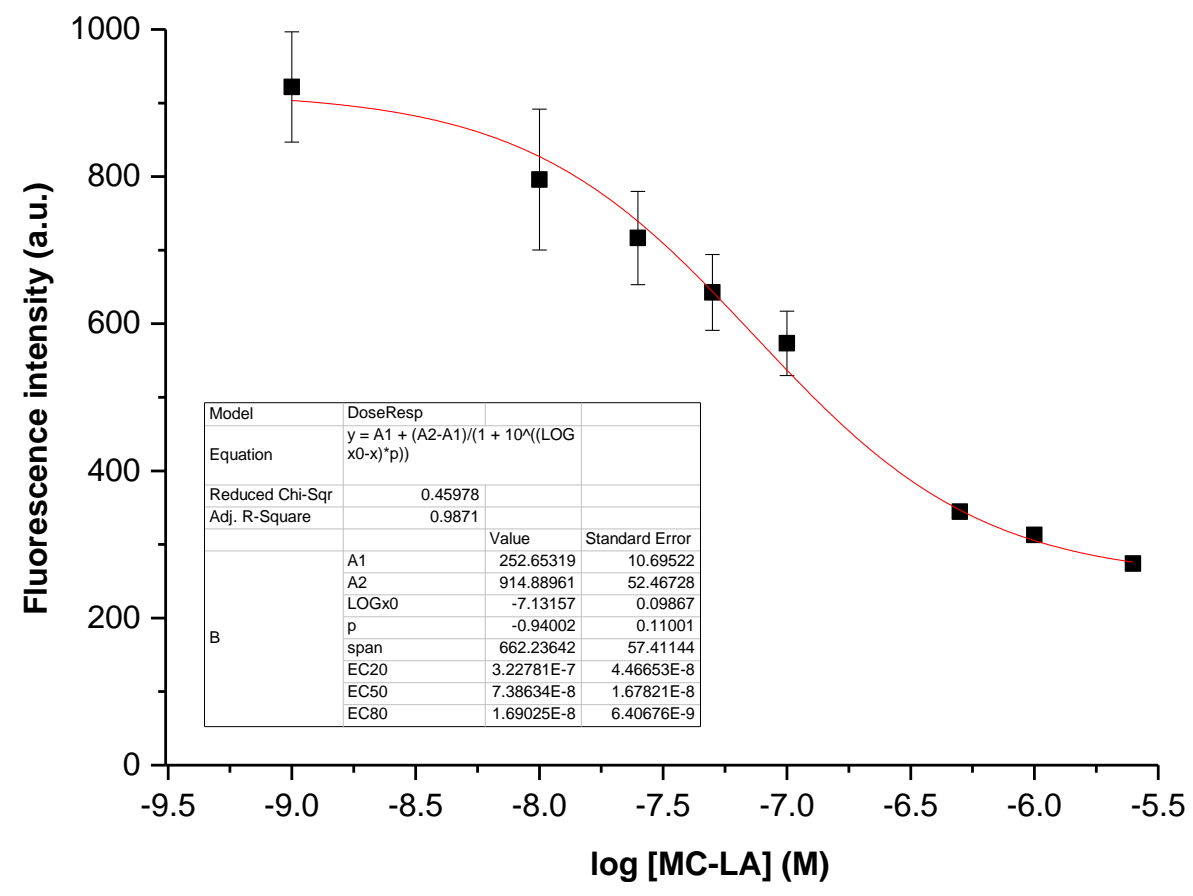

Figure S25. MC-LA calibration curve in 2-propanol. 


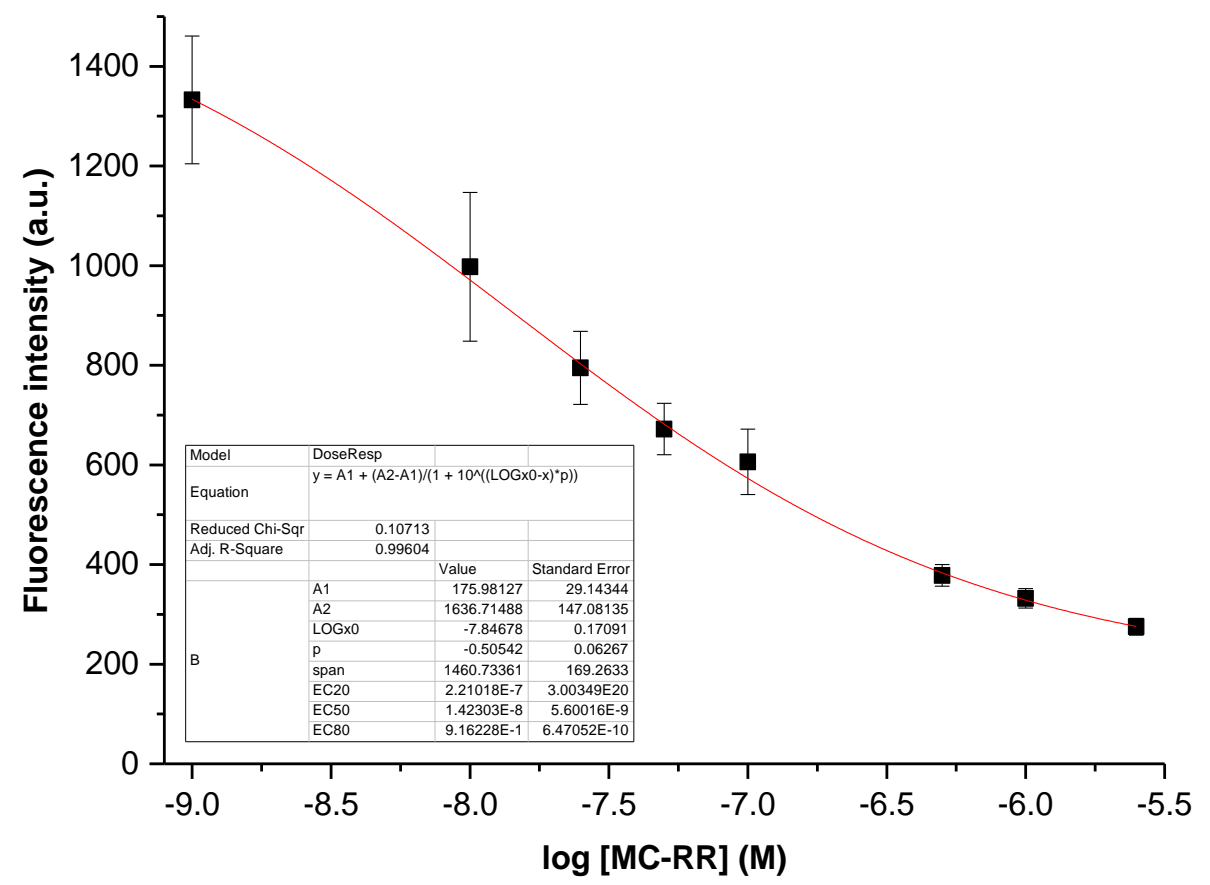

Figure S26. MC-RR calibration curve in 2-propanol.

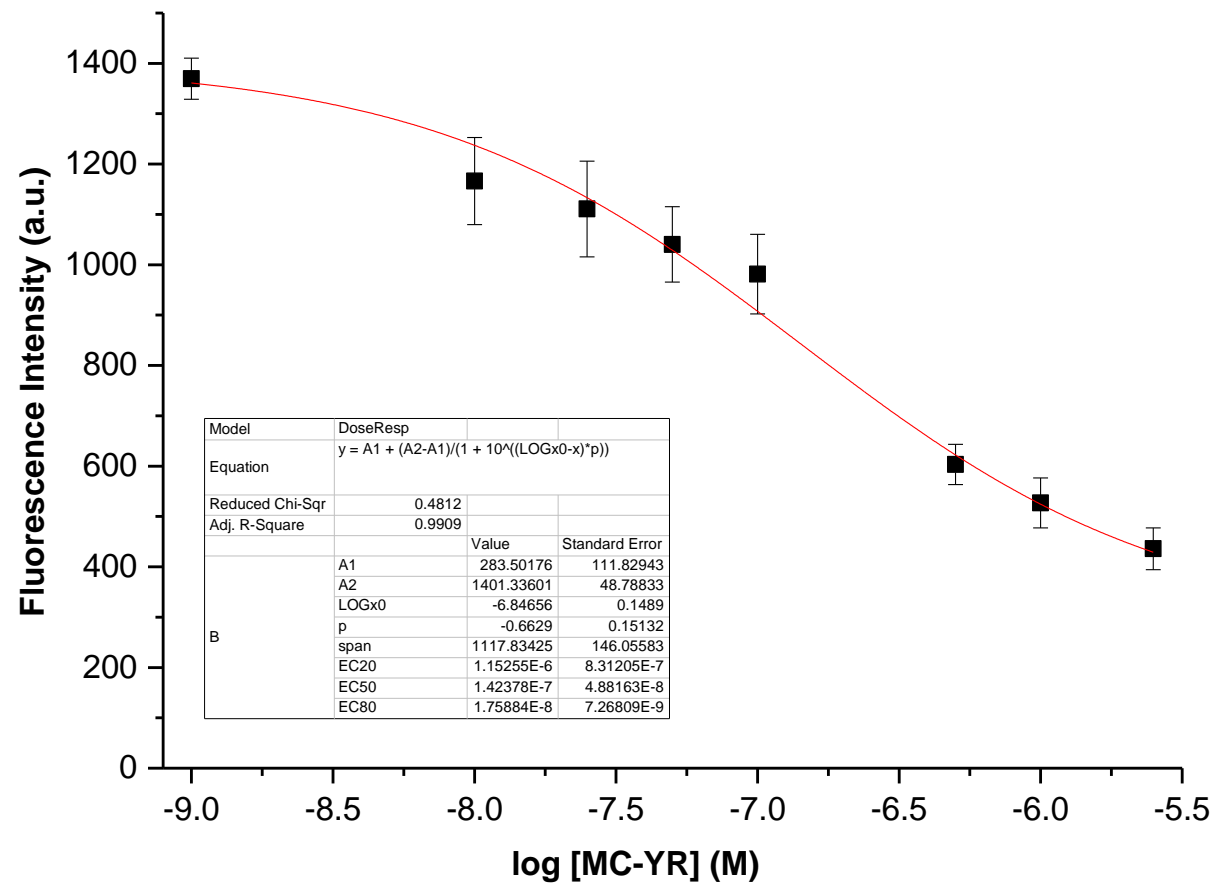

Figure S27. MC-YR calibration curve in 2-propanol. 


\subsection{Adsorption Kinetics}

Samples of $100 \mu \mathrm{L}$ of a TpBD-(CF $)_{2}$, TpBD-( $\left(\mathrm{NO}_{2}\right)_{2}$, or TpBD-( $\left(\mathrm{NH}_{2}\right)_{2}$ COF dispersion of $1 \mathrm{mg} \mathrm{mL} \mathrm{m}^{-1}$ in ultrapure water were spiked with a MC-LR, -LA, -RR, or -YR concentration of 1, 5, 10, 15, and $25 \mu \mathrm{mol} \mathrm{L} \mathrm{L}^{-1}$. Mixtures were incubated at $19^{\circ} \mathrm{C}$ under constant shaking at $1400 \mathrm{rpm}$, with incubation times of $0.5,5,10,30,60,100,120$, and $240 \mathrm{~min}$. The supernatant of the samples with incubation times of $60,100,120$, and 240 min were collected by centrifugation ( $\left.15000 \mathrm{rpm}, 19^{\circ} \mathrm{C}, 15 \mathrm{~min}\right)$. For the short times of the kinetics $(0.5,5,10$, and $30 \mathrm{~min})$, the isolation of supernatant was performed by filtration (0.22 $\mu \mathrm{m}$ hydrophilic PVDF membrane). Supernatants were collected and quantified for $M C-L R,-L A,-R R$, and $-Y R$. Two replicates of each concentration and each time were done. In case of samples with a concentration of $1 \mu \mathrm{mol} \mathrm{L^{-1 }}$ of $\mathrm{MC}$, the volume of experiment was increased to $200 \mu \mathrm{L}$, maintaining COF and MC concentration.

A)

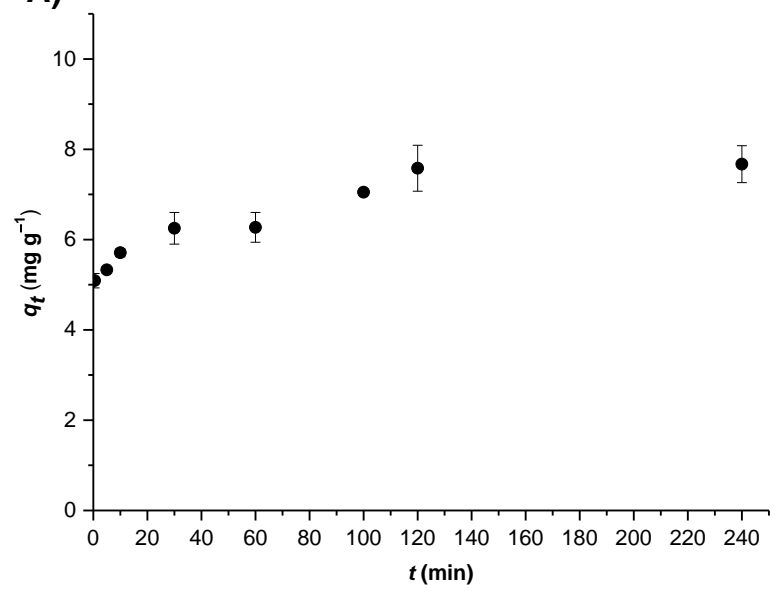

B)

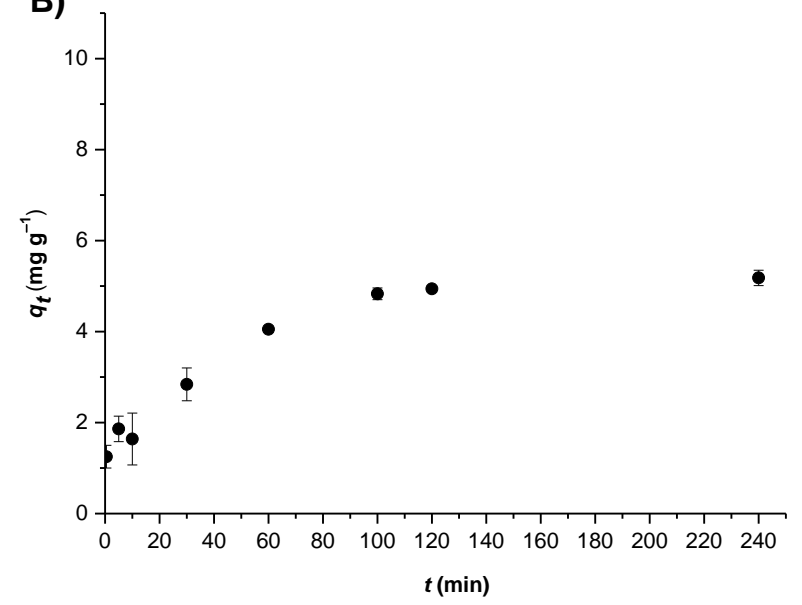

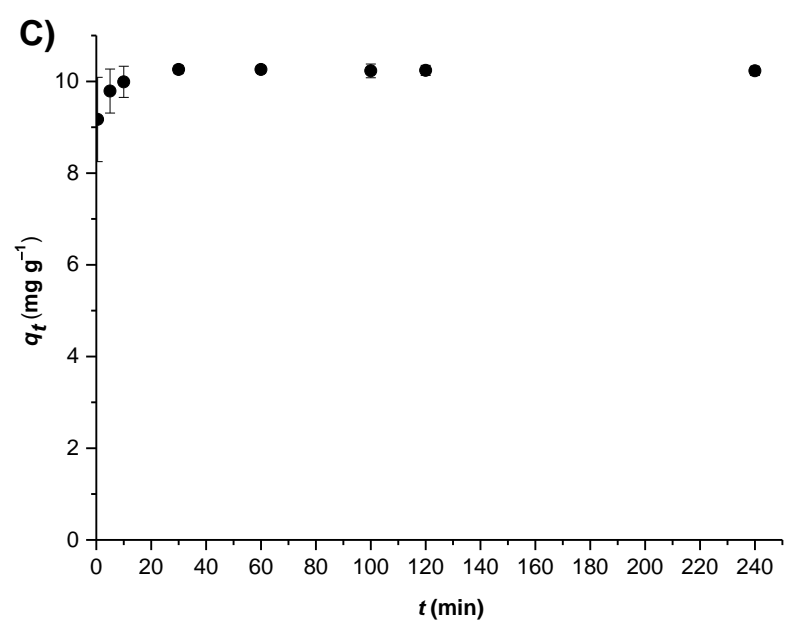

Figure S28. Adsorption kinetics at $10 \mu \mathrm{mol} \mathrm{L}^{-1}$ of: A) MC-LA; B) MC-RR; and C) MC-YR in TpBD-(CF $)_{2}$, expressed as quantity adsorbed, $q_{t}\left(\mathrm{mg} \mathrm{g}^{-1}\right)$ in function of time, $0.5,5,10,30,60,100,120$, and $240 \mathrm{~min}$, at $19{ }^{\circ} \mathrm{C}$ in ultrapure water at $\mathrm{pH} \mathrm{6-7}\left[\mathrm{C}_{0}(\mathrm{COF})=1 \mathrm{mg} \mathrm{mL}^{-1}\right]$. Results are expressed as the mean of three independent experiments with measurements performed in duplicates. Error bars correspond to the standard deviation of the mean. 
Table S1. Rate of adsorption of MC-LA, MC-LR, MC-RR, and MC-YR in COF derivatives until reaching the equilibrium of adsorption.

\begin{tabular}{|c|c|c|c|c|c|c|c|c|}
\hline & \multicolumn{2}{|c|}{ MC-LA } & \multicolumn{2}{|c|}{ MC-LR } & \multicolumn{2}{|c|}{ MC-RR } & \multicolumn{2}{|c|}{ MC-YR } \\
\hline & $\begin{array}{c}\text { Equilibrium } \\
\text { time } \\
\text { (min) }\end{array}$ & $\begin{array}{c}\text { Slope } \\
\text { initial } \\
\text { adsorption }\end{array}$ & $\begin{array}{c}\text { Equilibrium } \\
\text { time } \\
\text { (min) }\end{array}$ & $\begin{array}{c}\text { Slope } \\
\text { initial } \\
\text { adsorption }\end{array}$ & $\begin{array}{c}\text { Equilibrium } \\
\text { time } \\
\text { (min) }\end{array}$ & $\begin{array}{c}\text { Slope } \\
\text { initial } \\
\text { adsorption }\end{array}$ & $\begin{array}{c}\text { Equilibrium } \\
\text { time } \\
\text { (min) }\end{array}$ & $\begin{array}{c}\text { Slope } \\
\text { initial } \\
\text { adsorption }\end{array}$ \\
\hline TpBD- $\left(\mathrm{CF}_{3}\right)_{2}$ & 120 & $\begin{array}{c}0.01772 \pm \\
0.00067\end{array}$ & 100 & $\begin{array}{c}0.04152 \pm \\
0.00454\end{array}$ & 100 & $\begin{array}{c}0.03287 \pm \\
0.0059\end{array}$ & 10 & $\begin{array}{c}0.06691 \pm \\
0.02807\end{array}$ \\
\hline $\mathrm{TpBD}-\left(\mathrm{NO}_{2}\right)_{2}$ & & & & & 100 & $\begin{array}{c}0.04372 \pm \\
0.01064\end{array}$ & & \\
\hline TpBD- $\left(\mathrm{NH}_{2}\right)_{2}$ & 10 & $\begin{array}{c}0.03798 \pm \\
0.00121\end{array}$ & & & & & & \\
\hline
\end{tabular}

\subsection{Adsorption and desorption assays}

For adsorption, two replicates of $100 \mu \mathrm{L}$ of a TpBD-(CF $)_{2}$, TpBD- $\left(\mathrm{NO}_{2}\right)_{2}$, or TpBD- $\left(\mathrm{NH}_{2}\right)_{2}$ COF dispersion of $1 \mathrm{mg} \mathrm{mL}^{-1}$ in ultrapure water were spiked with a MC-LR, -LA, -RR, or -YR concentration of $10 \mu \mathrm{mol} \mathrm{L} \mathrm{L}^{-1}$. Mixtures were incubated at $19{ }^{\circ} \mathrm{C}$ under constant shaking at $1400 \mathrm{rpm}$ for $240 \mathrm{~min}$. After this time, the supernatant of the samples was collected by centrifugation $\left(15000 \mathrm{rpm}, 19^{\circ} \mathrm{C}\right.$, $15 \mathrm{~min})$, and analyzed for MC quantification. The pellets were washed with ultrapure water $(100 \mu \mathrm{L})$ under constant shaking at $1400 \mathrm{rpm}$ for $10 \mathrm{~min}$, and collected by centrifugation $\left(15000 \mathrm{rpm}, 19^{\circ} \mathrm{C}\right.$, $15 \mathrm{~min}$ ). With regard to desorption, the pellets obtained from the adsorption assay were suspended in $200 \mu \mathrm{L}$ of propan-2-ol and incubated overnight at $4{ }^{\circ} \mathrm{C}$ under constant shaking of $1400 \mathrm{rpm}$. Then, the samples were centrifuged $\left(15000 \mathrm{rpm}, 19^{\circ} \mathrm{C}, 15 \mathrm{~min}\right.$ ), and the supernatants analyzed for $\mathrm{MC}$ quantification.

Table S2. Amount of MC-LA, MC-LR, MC-RR, and MC-YR adsorbed and desorbed in equilibrium, $q_{\mathrm{e}}\left(\mathrm{mg} \mathrm{g}^{-1}\right)$, by TpBD-(CF$)_{2}, \mathrm{TpBD}-\left(\mathrm{NO}_{2}\right)_{2}$, and TpBD-(NH $\left.)_{2}\right)_{2} \mathrm{COF}$.

\begin{tabular}{|c|c|c|c|c|c|c|c|c|}
\hline & \multicolumn{2}{|c|}{ MC-LA } & \multicolumn{2}{|c|}{ MC-LR } & \multicolumn{2}{|c|}{ MC-RR } & \multicolumn{2}{|c|}{ MC-YR } \\
\hline & $\begin{array}{c}\text { Adsorption } \\
q_{e}\end{array}$ & $\begin{array}{c}\text { Desorption } \\
\qquad q_{e}\end{array}$ & $\begin{array}{c}\text { Adsorption } \\
q_{e}\end{array}$ & $\begin{array}{c}\text { Desorption } \\
q_{e}\end{array}$ & $\begin{array}{c}\text { Adsorption } \\
q_{e}\end{array}$ & $\begin{array}{c}\text { Desorption } \\
q_{e}\end{array}$ & $\begin{array}{c}\text { Adsorption } \\
q_{e}\end{array}$ & $\begin{array}{c}\text { Desorption } \\
q_{e}\end{array}$ \\
\hline TpBD- $\left(\mathrm{CF}_{3}\right)_{2}$ & $6.62 \pm 0.3$ & $1.38 \pm 0.47$ & $7.76 \pm 0.38$ & $2.01 \pm 1.3$ & $3.43 \pm 0.49$ & $1.35 \pm 0.47$ & $9.24 \pm 0.34$ & $7.41 \pm 1.01$ \\
\hline $\mathrm{TpBD}-\left(\mathrm{NO}_{2}\right)_{2}$ & $3.62 \pm 1.42$ & $0.93 \pm 0.62$ & $8.29 \pm 0.17$ & $1.81 \pm 1.42$ & $7.12 \pm 0.59$ & $0.06 \pm 0.04$ & $8.85 \pm 0.29$ & $2.52 \pm 1.44$ \\
\hline TpBD- $\left(\mathrm{NH}_{2}\right)_{2}$ & $8.58 \pm 0.07$ & $5.71 \pm 1.28$ & $8.82 \pm 0.06$ & $3.69 \pm 1.73$ & $2.26 \pm 0.89$ & $0.21 \pm 0.04$ & $9.62 \pm 0.1$ & $7.84 \pm 1.06$ \\
\hline
\end{tabular}




\subsection{Isotherms at $19^{\circ} \mathrm{C}$}

Isotherms obtained at $19{ }^{\circ} \mathrm{C}$ were fitted with the Freundlich and Langmuir models to determine the best equilibrium adsorption isotherm.

\section{Freundlich model}

Freundlich equation is expressed as:

$\log q_{e}=\left(\frac{1}{n}\right) \log C_{e}+\log K_{F}$

where $q_{\mathrm{e}}$ is the amount of adsorbate adsorbed onto COF in equilibrium ( $\mathrm{mg} \mathrm{g}^{-1}$ ), $C_{\mathrm{e}}$ is the concentration of adsorbate in the equilibrium state $\left(\mathrm{mg} \mathrm{L}^{-1}\right)$, and $n$ and $K_{\mathrm{F}}$ are characteristic constants. $K_{\mathrm{F}}$ is an indicator of the adsorption capacity in the Freundlich theory. This constant is a parameter used to evaluate the strength of adsorption process. ${ }^{10}$

The maximum adsorption capacity $\left(q_{m}\right)$ can be calculated from the following equation:

$q_{m}=K_{F} c_{0}^{1 / n}$

where $C_{0}$ is the initial and highest concentration of the adsorbate in solution $\left(\mathrm{mg} \mathrm{L}^{-1}\right)$.

\section{Langmuir model}

Langmuir equation is expressed as:

$\frac{C_{e}}{q_{e}}=\left(\frac{1}{q_{m}}\right) C_{e}+\frac{1}{q_{m} K_{L}}$

where $q_{\mathrm{e}}$ is the amount of adsorbate adsorbed onto COF in equilibrium (mg g $\left.{ }^{-1}\right), C_{\mathrm{e}}$ is the concentration of adsorbate in the equilibrium state $\left(\mathrm{mg} \mathrm{L}^{-1}\right), q_{m}$ is the maximum adsorption capacity $\left(\mathrm{mg} \mathrm{g}^{-1}\right)$, and $K_{\mathrm{L}}$ is the characteristic Langmuir model constant.

The main characteristics of the Langmuir isotherm can be expressed by a dimensionless constant described as the separation factor $R_{\mathrm{L}}$, which is an important equilibrium parameter.

$R_{L}=\frac{1}{1+K_{L} C_{0}}$

Where $C_{0}$ is the initial and highest concentration of the adsorbate in solution ( $\mathrm{mg} \mathrm{L}^{-1}$ ).

$R_{L}>1$ indicates the adsorption to be unfavorable, $R_{\mathrm{L}}=1$ is linear, $0<R_{L}<1$ is favorable, and $R_{\mathrm{L}}=0$ is irreversible. 
Table S3. Freundlich and Langmuir isotherm equation constants and correlation coefficient.

\begin{tabular}{ll}
\hline MC-LR onto TpBD-( $\left(\mathrm{CF}_{3}\right)_{2}$ COF \\
\hline Freundlich model & \\
Regression equation & $\log q_{e}=(1.037 \pm 0.132) \log C_{e}-(0.263 \pm 0.129)$ \\
$K_{F}\left(\mathrm{mg}^{1-1 / n} \mathrm{~g}^{-1} \mathrm{~L}^{1 / n}\right)$ & 0.546 \\
$1 / n$ & $1.037 \pm 0.132$ \\
$n$ & 0.964 \\
$\mathrm{R}^{2}$ & 0.938
\end{tabular}

\section{Langmuir model}

$\begin{array}{ll}\text { Regression equation } & \frac{C e}{q_{e}}=(0.0097 \pm 0.02958) C_{e}+(1.6505 \pm 0.41127) \\ K_{L}\left(\mathrm{~L} \mathrm{mg}^{-1}\right) & 0.006 \\ \mathrm{R}^{2} & -0.287\end{array}$

\begin{tabular}{ll}
\hline MC-LA onto TpBD-( $\left.\mathrm{NH}_{2}\right)_{2}$ COF \\
\hline Freundlich model & \\
Regression equation & $\log q_{e}=(0.9294 \pm 0.04343) \log C_{e}+(0.0092 \pm 0.04113)$ \\
$K_{F}\left(\mathrm{mg}^{1-1 / n} \mathrm{~g}^{-1} \mathrm{~L}^{1 / n}\right)$ & 1.021 \\
$1 / n$ & $0.929 \pm 0.043$ \\
$n$ & 1.076 \\
$\mathrm{R}^{2}$ & 0.991
\end{tabular}

\section{Langmuir model}

Regression equation $\frac{C e}{q_{e}}=(0.0168 \pm 0.00417) C_{e}+(0.9545 \pm 0.05302)$

$\begin{array}{ll}K_{L}\left(\mathrm{~L} \mathrm{mg}^{-1}\right) & 0.018 \\ \mathrm{R}^{2} & 0.791\end{array}$

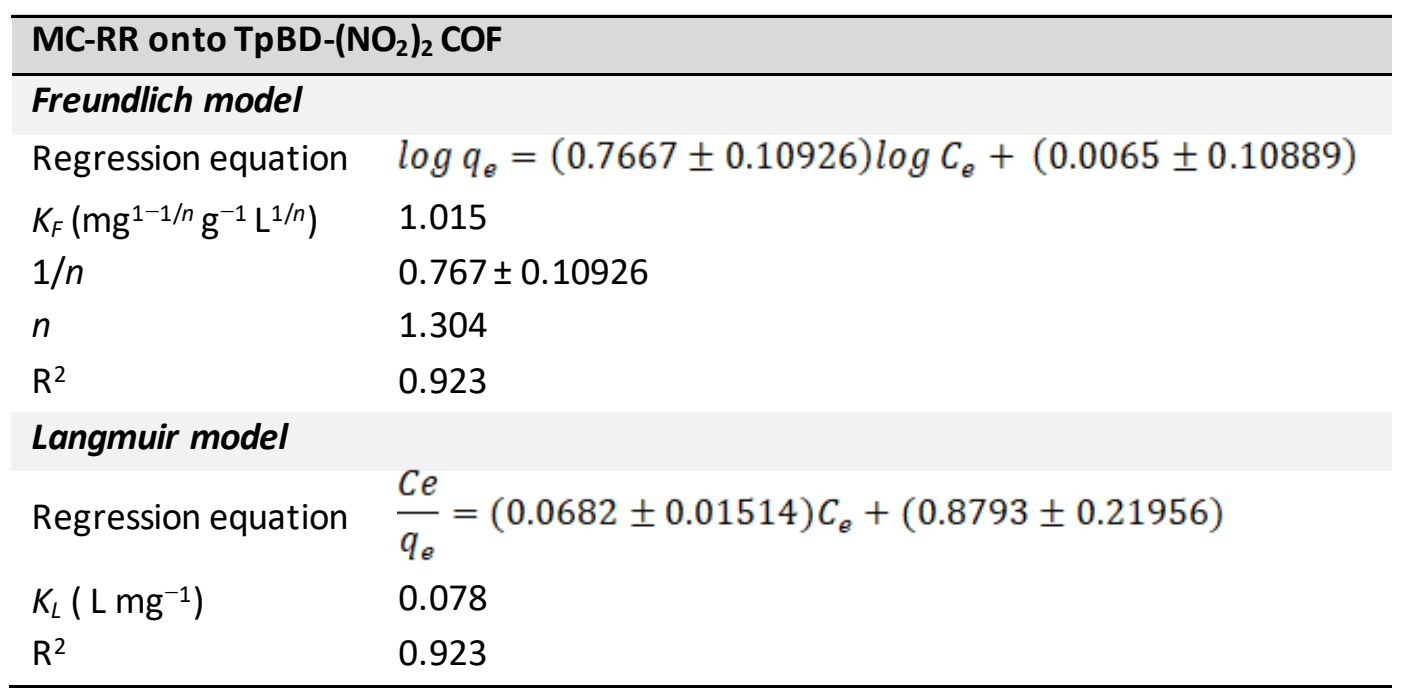


(a)
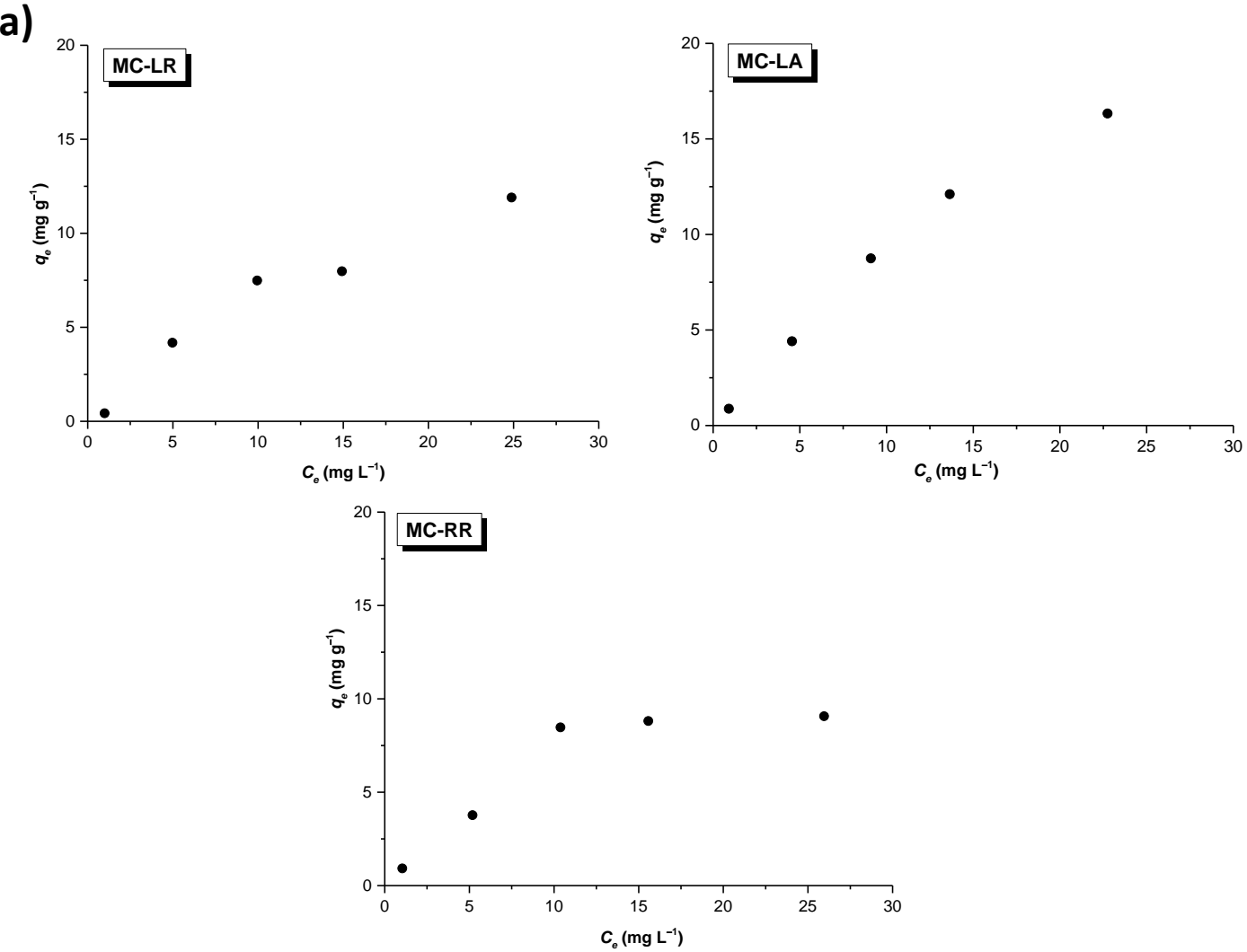

(b)
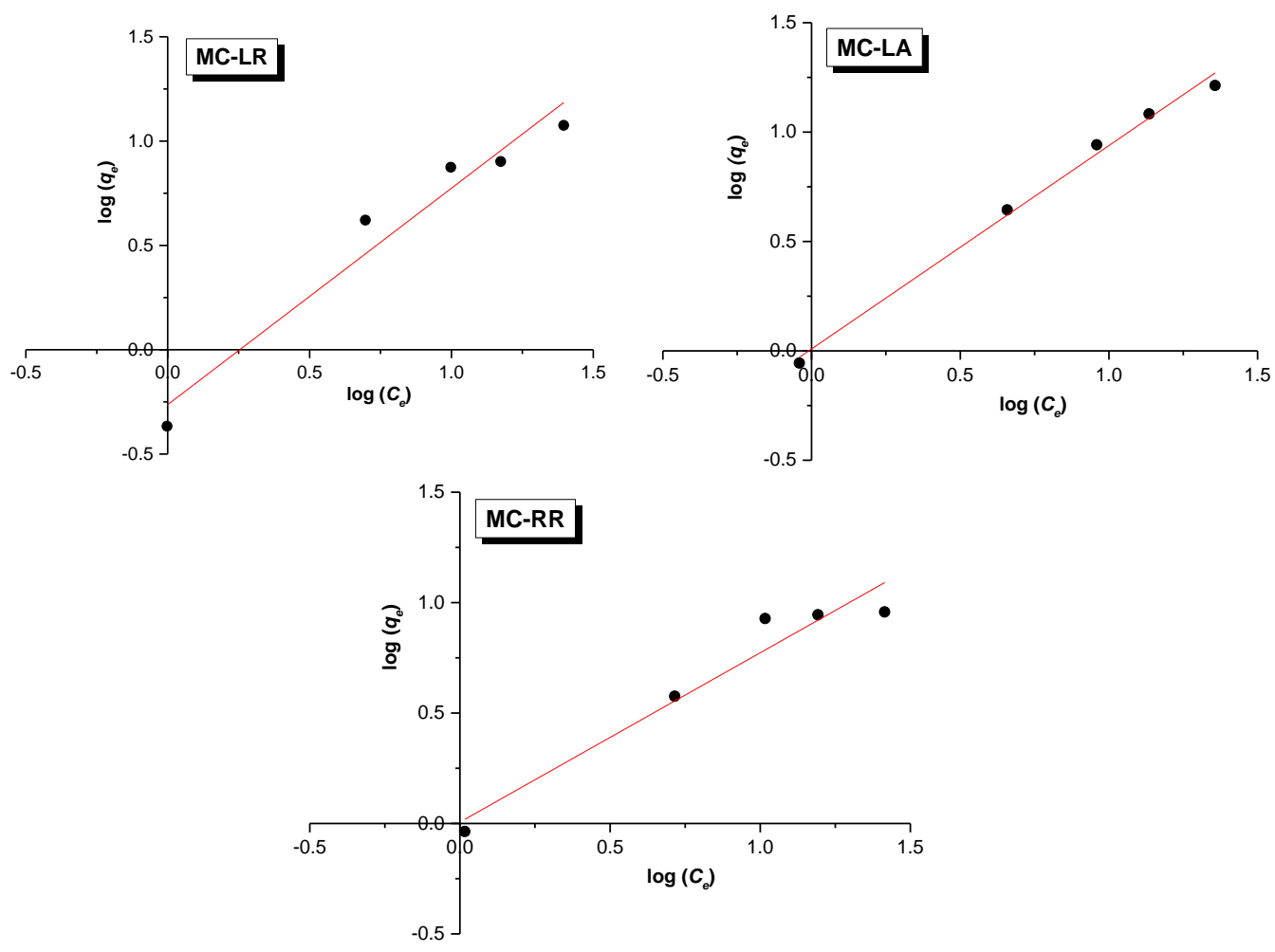

Figure S29. (a) Amount of microcystin adsorbed in equilibrium (120 $\mathrm{min}), q_{e}\left(\mathrm{mg} \mathrm{g}^{-1}\right)$, as a function of microcystin concentration in equilibrium, $C_{e}\left(\mathrm{mg} \mathrm{L}^{-1}\right)$; (b) Linear regression of the Freundlich isotherm for the experimental adsorption of MC-LR, $-\mathrm{LA}$, and $-\mathrm{RR}$ by TpBD- $\left(\mathrm{CF}_{3}\right)_{2}, \mathrm{TpBD}-\left(\mathrm{NH}_{2}\right)_{2}$, and TpBD- $\left(\mathrm{NO}_{2}\right)_{2}$, respectively. 


\section{Adsorption mechanism}

A)

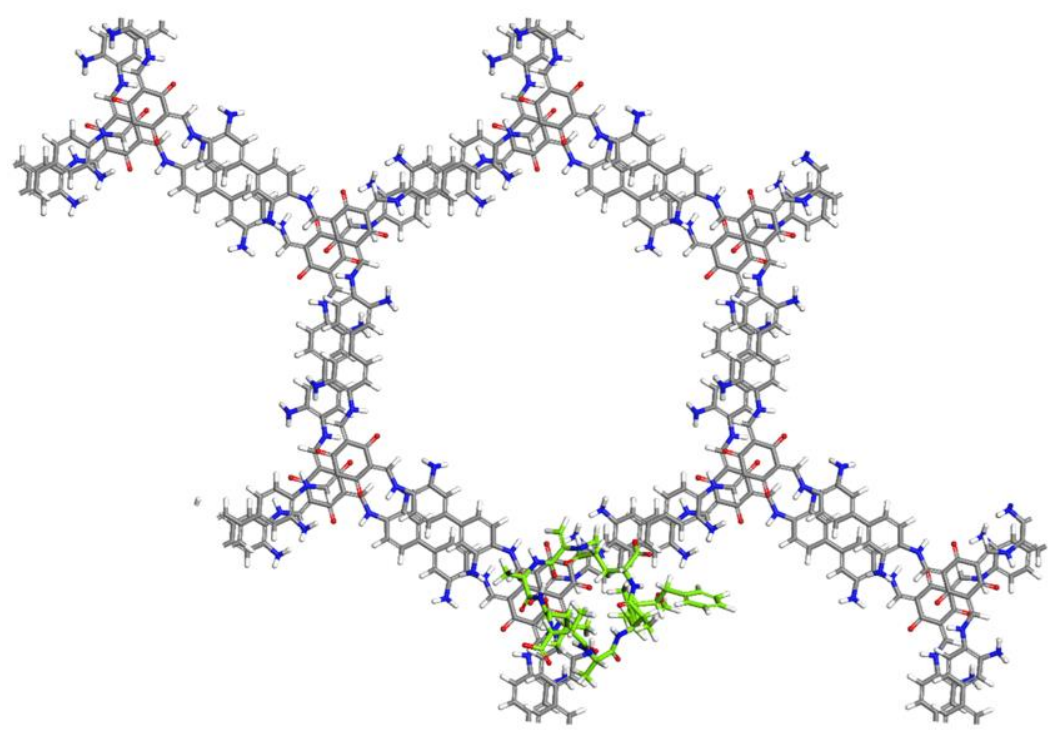

B)

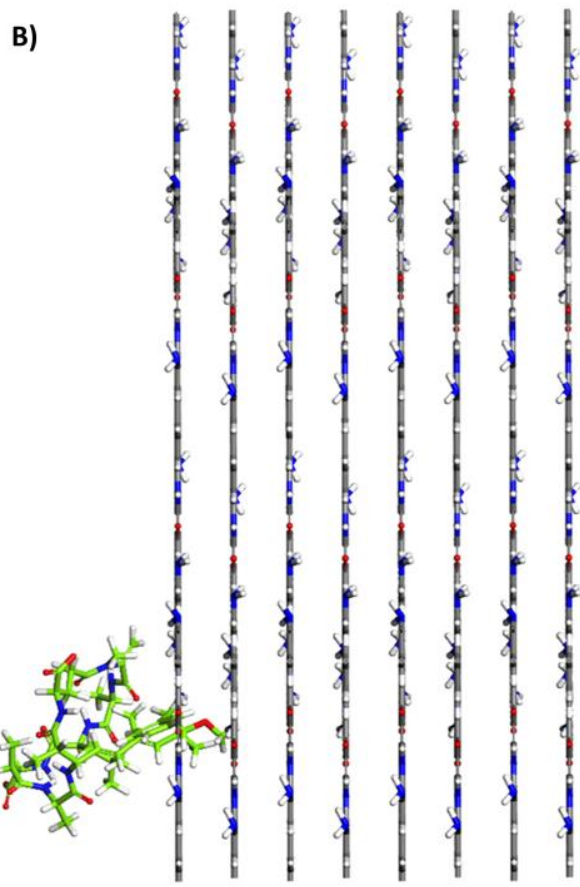

Figure S30. A top view along $z$ axis $(A)$ and side view along $x$ axis $(B)$ of the atomistic model of MC-LA in TpBD- $\left(\mathrm{NH}_{2}\right)_{2}$, located on the surface of COF.

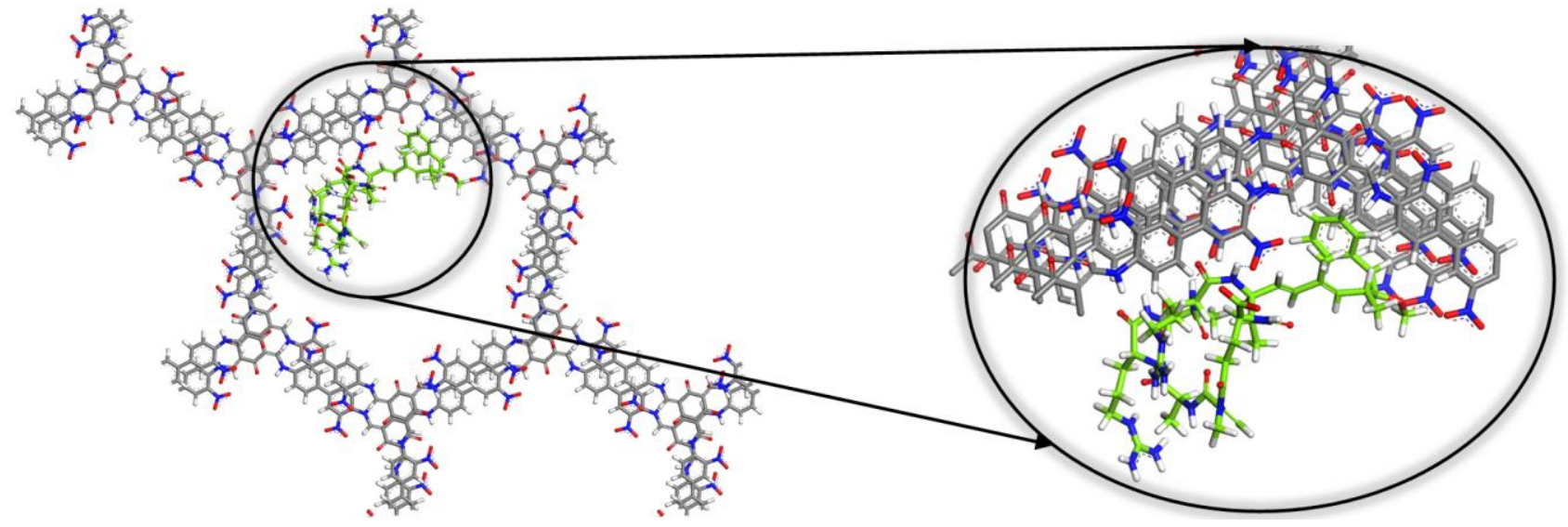

Figure S31. A top view along $z$ axis of the atomistic model of MC-RR in TpBD- $\left(\mathrm{NO}_{2}\right)_{2}$. 
12. Comparison of TpBD- $\left(\mathrm{CF}_{3}\right)_{2}, \mathrm{TpBD}-\left(\mathrm{NO}_{2}\right)_{2}$, and TpBD- $\left(\mathrm{NH}_{2}\right)_{2}$ adsorption efficiencies with other reported adsorbents for adsorption of MC-LA, MC-LR, MC-RR, and MC-YR

Table S4. Reported performance of MCs adsorbents. $q_{\mathrm{m}}$ as the maximum adsorption capacity, in $\mathrm{mg}$ $\mathrm{g}^{-1}$, and $t_{\mathrm{eq}}$ as the time needed to reach the equilibrium, in minutes. Concentration of adsorbent and the maximum MC concentration used in the studies are expressed for reference.

\begin{tabular}{|c|c|c|c|c|}
\hline $\begin{array}{c}\text { Adsorbent } \\
\left(\mathrm{mg} \mathrm{mL}^{-1}\right)\end{array}$ & $\begin{array}{c}\text { MCs } \\
\left(\mathrm{mg} \mathrm{L}^{-1}\right) \\
\end{array}$ & $\begin{array}{c}q_{\mathrm{m}} \\
\left(\mathrm{mg} \mathrm{g}^{-1}\right)\end{array}$ & $\begin{array}{c}t_{e q} \\
(\min )\end{array}$ & Reference \\
\hline \multicolumn{5}{|c|}{ MC-LR } \\
\hline $\begin{array}{l}\text { Purolite }^{\circledR} \mathrm{A} 860 \text { resin } \\
\left(0.2 \mathrm{mg} \mathrm{mL}^{-1}\right)\end{array}$ & 0.025 & 0.13 & 40 & 11 \\
\hline $\begin{array}{l}\text { HP20 resin } \\
\text { SP700 resin } \\
\left(50 \mathrm{mg} \mathrm{mL}^{-1}\right)\end{array}$ & 148.86 & $\begin{array}{l}3.3 \\
2.5\end{array}$ & $\begin{array}{l}30 \\
15\end{array}$ & 12 \\
\hline $\begin{array}{l}\mathrm{Fe}_{3} \mathrm{O}_{4} @ \mathrm{PDA} @ \gamma-\mathrm{CDP} \\
\left(0.2 \mathrm{mg} \mathrm{mL}^{-1}\right)\end{array}$ & 0.05 & 0.34 & 30 & 13 \\
\hline $\begin{array}{l}\mathrm{Fe}_{3} \mathrm{O}_{4} @ \mathrm{SiO}_{2} @ \beta-\mathrm{CDP} \\
\left(2 \mathrm{mg} \mathrm{mL} \mathrm{mL}^{-1}\right)\end{array}$ & 0.025 & 0.24 & 30 & 14 \\
\hline $\begin{array}{l}\text { Microgel-Fe(III) complex } \\
\left(0.15 \mathrm{mg} \mathrm{mL}^{-1}\right)\end{array}$ & 10 & 164.47 & 12 & 15 \\
\hline $\begin{array}{l}\text { Macroporous magnetic-silica } \\
\text { composite } \\
\left(3 \mathrm{mg} \mathrm{mL}^{-1}\right)\end{array}$ & 0.010 & 0.0033 & 10 & 16 \\
\hline $\begin{array}{l}\mathrm{m}-\mathrm{Fe}_{3} \mathrm{O}_{4} @ \mathrm{C}-\mathrm{NPs} \\
\text { mesoporous-Si@ } \mathrm{Fe}_{3} \mathrm{O}_{4}-\mathrm{NPs}\end{array}$ & $\begin{array}{c}0.05 \\
0.013\end{array}$ & $\begin{array}{l}0.17 \\
0.10\end{array}$ & 60 & 17 \\
\hline $\begin{array}{l}\mathrm{Fe}_{3} \mathrm{O}_{4} / \text { Chitosan } \\
\left(25 \mathrm{mg} \mathrm{mL}^{-1}\right)\end{array}$ & 6.47 & 0.59 & 180 & 18 \\
\hline $\begin{array}{l}\text { MIL-100(Al) xerogel } \\
\left(1 \mathrm{mg} \mathrm{mL}^{-1}\right)\end{array}$ & 10 & 7.13 & 60 & 19 \\
\hline $\begin{array}{l}\text { Graphene oxide } \\
\left(0.5 \mathrm{mg} \mathrm{mL}^{-1}\right)\end{array}$ & 0.5 & 1.70 & 5 & 20 \\
\hline $\begin{array}{l}\text { Granular activated carbon } \\
\left(0.5 \mathrm{mg} \mathrm{mL}^{-1}\right)\end{array}$ & 0.5 & 1.48 & n.d & 20 \\
\hline $\begin{array}{l}\text { PAC-Fe(III) } \\
\left(0.15 \mathrm{mg} \mathrm{mL}^{-1}\right)\end{array}$ & 10 & 126.61 & 120 & 21 \\
\hline $\begin{array}{l}\text { Ordered Mesoporous carbon } \\
\left(0.01 \mathrm{mg} \mathrm{mL}^{-1}\right)\end{array}$ & 10 & $87-526$ & 240 & 22 \\
\hline $\begin{array}{l}\text { Functionalized mesoporous } \\
\text { materials } \\
\left(0.1 \mathrm{mg} \mathrm{mL}^{-1}\right)\end{array}$ & 1 & $23.03-37.87$ & 250 & 23 \\
\hline
\end{tabular}




\begin{tabular}{|c|c|c|c|c|}
\hline $\begin{array}{l}\text { TpBD-(CF })_{2} \text { COF } \\
\left(1 \mathrm{mg} \mathrm{mL}^{-1}\right)\end{array}$ & 24.9 & 15.31 & 100 & This work \\
\hline \multicolumn{5}{|c|}{ MC-RR } \\
\hline $\begin{array}{l}\mathrm{Fe}_{3} \mathrm{O}_{4} @ \mathrm{PDA} @ \gamma-\mathrm{CDP} \\
\left(0.2 \mathrm{mg} \mathrm{mL}^{-1}\right)\end{array}$ & 0.05 & 0.37 & 30 & 13 \\
\hline $\begin{array}{l}\mathrm{Fe}_{3} \mathrm{O}_{4} @ \mathrm{SiO}_{2} @ \beta-\mathrm{CDP} \\
\left(2 \mathrm{mg} \mathrm{mL}^{-1}\right)\end{array}$ & 0.025 & 0.24 & 30 & 14 \\
\hline $\begin{array}{l}\text { Graphene oxide } \\
\left(0.5 \mathrm{mg} \mathrm{mL}^{-1}\right)\end{array}$ & 0.50 & 1.88 & 5 & 20 \\
\hline $\begin{array}{l}\text { Granular activated carbon } \\
\left(0.5 \mathrm{mg} \mathrm{mL}^{-1}\right)\end{array}$ & 0.5 & 1.03 & - & 20 \\
\hline $\begin{array}{l}\text { TpBD- }\left(\mathrm{NO}_{2}\right)_{2} \text { COF } \\
\left(1 \mathrm{mg} \mathrm{mL}^{-1}\right)\end{array}$ & 25.96 & 12.32 & 100 & This work \\
\hline \multicolumn{5}{|c|}{ MC-YR } \\
\hline $\begin{array}{l}\mathrm{Fe}_{3} \mathrm{O}_{4} @ \mathrm{PDA} @ \gamma-\mathrm{CDP} \\
\left(0.2 \mathrm{mg} \mathrm{mL}^{-1}\right)\end{array}$ & 0.05 & 0.35 & 30 & 13 \\
\hline $\begin{array}{l}\mathrm{Fe}_{3} \mathrm{O}_{4} @ \mathrm{SiO}_{2} @ \beta-\mathrm{CDP} \\
(2 \mathrm{mg} \mathrm{mL})\end{array}$ & 0.025 & 0.21 & 30 & 14 \\
\hline \multicolumn{5}{|c|}{ MC-LA } \\
\hline $\begin{array}{l}\text { TpBD- }\left(\mathrm{NH}_{2}\right)_{2} \text { COF } \\
\left(1 \mathrm{mg} \mathrm{mL}^{-1}\right)\end{array}$ & 22.75 & 18.64 & 10 & This work \\
\hline
\end{tabular}




\section{References}

1 Chong, J. H.; Sauer, M.; Patrick, B. O.; MacLachlan, M. J. Highly Stable Keto-Enamine Salicylideneanilines. Org. Lett. 2003, 5, 3823-3826.

2 Mellah, A.; Fernandes, S. P. S.; Rodríguez, R.; Otero, J.; Paz, J.; Cruces, J.; Medina, D. D.; Djamila, H.; Espiña, B.; Salonen, L. M. Adsorption of Pharmaceutical Pollutants from Water Using Covalent Organic Frameworks. Chem. Eur. J. 2018, 24, 10601-10605.

3 Lohse, M. S.; Stassin, T.; Naudin, G.; Wuttke, S.; Ameloot, R.; De Vos, D.; Medina, D. D.; Bein, T. Sequential Pore Wall Modification in a Covalent Organic Framework for Application in Lactic Acid Adsorption. Chem. Mater. 2016, 28, 626-631.

Dassault Systèmes BIOVIA Materials Studio 8.0, Dassault Systèmes, San Diego 2017.

5 Chandra, S.; Biswal, B. P.; Kandambeth, S.; Lukose, B.; Kunjir, S. M.; Chaudhary, M.; Ba bara o, R.; Heine, T.; Banerjee, R. Chemically Stable Multi-Layered Covalent Organic Nanosheets from Covalent Organic Frameworks via Mechanical Delamination Chemically Stable Multi-Layered Covalent Organic Nanosheets from Covalent Organic Frameworks via Mechanical Delamination. J. Am. Chem. Soc 2013, 135, 17853-17861.

Plimpton, S. Fast Parallel Algorithms for Short-Range Molecular Dynamics. J. Comput. Phys. 1995, 117, 1-19.

7 Sun, H.; Mumby, S. J.; Maple, J. R.; Hagler, A. T. An Ab Initio CFF93 All-Atom Force Field for Polycarbonates. J. Am. Chem. Soc. 1994, 116, 2978-2987.

Sun, H. Compass: An Ab Initio Force-Field Optimized for Condensed-Phase Applications Overview with Details on Alkane and Benzene Compounds. J. Phys. Chem. B 1998, 102, 73387364.

Heinz, H. Computational Screening of Biomolecular Adsorption and Self-Assembly on Nanoscale Surfaces. J. Comput. Chem. 2010, 31, 1564-1568.

10 E. Worch, Adsorption Technology In Water Treatment Fundamentals, processes, and modeling, De Fruyter, 2016.

Dixit, F.; Barbeau, B.; Mohseni, M. Removal of Microcystin-LR from Spiked Natural and Synthetic Waters by Anion Exchange. Sci. Total Environ. 2019, 655, 571-580.

12 Zhao, H.; Qiu, J.; Fan, H.; Li, A. Mechanism and Application of Solid Phase Adsorption Toxin Tracking for Monitoring Microcystins. J. Chromatogr. A 2013, 1300, 159-164.

13 Huang, C.; Wang, Y.; Huang, Q.; He, Y.; Zhang, L. Magnetic -Cyclodextrin Polymer with Compatible Cavity Promote the Magnetic Solid-Phase Extraction of Microcystins in Water Samples. Anal. Chim. Acta 2019, 1054, 38-46.

14 Zhang, W.; Lin, M.; Wang, M.; Tong, P.; Lu, Q.; Zhang, L. Magnetic Porous $\beta$-Cyclodextrin Polymer for Magnetic Solid-Phase Extraction of Microcystins from Environmental Water Samples. J. Chromatogr. A 2017, 1503, 1-11.

Dai, G.; Quan, C.; Zhang, X.; Liu, J.; Song, L.; Gan, N. Fast Removal of Cyanobacterial Toxin Microcystin-LR by a Low-Cytotoxic Microgel-Fe(III) Complex. Water Res. 2012, 46, 1482-1489. Microcystin. Microporous Mesoporous Mater. 2010, 130, 26-31. 
17 González-Jartin, J. M.; Alves, L. C.; Alfonso, A.; Piñeiro, Y.; Vilar, S. Y.; Rodriguez, I.; Gomez, M. G.; Osorio, Z. V.; Sainz, M. J.; Vieytes, M. R.; Rivas, J.; Botana, L. M. Magnetic Nanost ructures for Marine and Freshwater Toxins Removal. Chemosphere 2020, 256, 127019.

18 He, Y.; Wu, P.; Li, G.; Li, L.; Yi, J.; Wang, S.; Lu, S.; Ding, P.; Chen, C.; Pan, H. Optimization on Preparation of Fe304/Chitosan as Potential Matrix Material for the Removal of MicrocystinLR and Its Evaluation of Adsorption Properties. Int. J. Biol. Macromol. 2020, 156, 1574-1583.

19 Xia, W.; Zhang, X.; Xu, L.; Wang, Y.; Lin, J.; Zou, R. Facile and Economical Synthesis of MetalOrganic Framework MIL-100(Al) Gels for High Efficiency Removal of Microcystin-LR. RSC Adv. 2013, 3, 11007-11013.

20 Pavagadhi, S.; Tang, A. L. L.; Sathishkumar, M.; Loh, K. P.; Balasubramanian, R. Removal of Microcystin-LR and Microcystin-RR by Graphene Oxide: Adsorption and Kinetic Experiments. Water Res. 2013, 47, 4621-4629.

21 Dai, G.; Gan, N.; Song, L.; Fang, S.; Peng, N. Fast Adsorption of Microcystin-LR by Fe(III)Modified Powdered Activated Carbon. J. Oceanol. Limnol. 2018, 36, 1103-1111.

22 Teng, W.; Wu, Z.; Fan, J.; Chen, H.; Feng, D.; Lv, Y.; Wang, J.; Asiri, A. M.; Zhao, D. Ordered Mesoporous Carbons and Their Corresponding Column for Highly Efficient Removal of Microcystin-LR. Energy Environ. Sci. 2013, 6, 2765-2776.

23 Park, J. A.; Kang, J. K.; Jung, S. M.; Choi, J. W.; Lee, S. H.; Yargeau, V.; Kim, S. B. Investigating Microcystin-LR Adsorption Mechanisms on Mesoporous Carbon, Mesoporous Silica, and Their Amino-Functionalized Form: Surface Chemistry, Pore Structures, and Molecular Characteristics. Chemosphere 2020, 247, 125811. 